\title{
What are the respiratory effects of e-cigarettes?
}

\author{
Jeffrey E Gotts, ${ }^{1}$ Sven-Eric Jordt, ${ }^{2,3}$ Rob McConnell, ${ }^{4}$ Robert Tarran ${ }^{5,6}$
}

\section{(?) $(1)$ OPEN ACCESS}

Check for updates

${ }^{1}$ Department of Medicine,

University of California San

Francisco, San Francisco, CA, USA

${ }^{2}$ Department of Anesthesiology,

Duke University, Durham,

NC, USA

${ }^{3}$ Yale Center for the Study

of Tobacco Products and

Addiction, Department of

Psychiatry, Yale School of

Medicine, New Haven, CT, USA

${ }^{4}$ Department of Preventive

Medicine, University of

Southern California, CA, USA

${ }^{5}$ Marsico Lung Institute, The University of North Carolina at Chapel Hill, Chapel Hill, NC 27599 USA

${ }^{6}$ Department of Cell Biology and Physiology, The University of North Carolina at Chapel Hill, Chapel Hill, NC 27599 USA

Correspondence to: R Tarran robert_tarran@med.unc.edu

Cite this as: $B M J$ 2019;366:15275 http://dx.doi.org/10.1136/bmj.l5275

Series explanation: State of the Art Reviews are commissioned on the basis of their relevance to academics and specialists in the US and internationally. For this reason they are written predominantly by US authors.

\begin{abstract}
Electronic cigarettes (e-cigarettes) are alternative, non-combustible tobacco products that generate an inhalable aerosol containing nicotine, flavors, propylene glycol, and vegetable glycerin. Vaping is now a multibillion dollar industry that appeals to current smokers, former smokers, and young people who have never smoked. E-cigarettes reached the market without either extensive preclinical toxicology testing or long term safety trials that would be required of conventional therapeutics or medical devices. Their effectiveness as a smoking cessation intervention, their impact at a population level, and whether they are less harmful than combustible tobacco products are highly controversial. Here, we review the evidence on the effects of e-cigarettes on respiratory health. Studies show measurable adverse biologic effects on organ and cellular health in humans, in animals, and in vitro. The effects of e-cigarettes have similarities to and important differences from those of cigarettes. Decades of chronic smoking are needed for development of lung diseases such as lung cancer or chronic obstructive pulmonary disease, so the population effects of e-cigarette use may not be apparent until the middle of this century. We conclude that current knowledge of these effects is insufficient to determine whether the respiratory health effects of e-cigarette are less than those of combustible tobacco products.
\end{abstract}

\begin{abstract}
Introduction
The lungs are a physiologic marvel, transmitting the entire cardiac output through around $2000 \mathrm{~km}$ of capillaries with each heartbeat and performing gas exchange in 300000000 alveoli with a surface area of about $70 \mathrm{~m}^{2}$. With every breath, this highly adapted and delicate organ is exposed to infectious and inflammatory environmental stimuli. As a result of innate and acquired immunity, inspired air is cleaned and humidified before it reaches the alveoli. However, a failure of these processes leads to infection, inflammation, lung damage, and impaired gas exchange.

In considering the effects of electronic cigarettes (e-cigarettes) on lung health, we begin with a brief history of traditional cigarettes. Cigarette smoking accelerated in the late 19th and early 20th centuries in tandem with the growth of mass production technologies and advertising. ${ }^{1}$ However, it was not until the 1930s that statisticians noted increased cancer mortality rates and thoracic surgeons reported an increase in pneumonectomy to remove lung cancers. ${ }^{2}$ Three decades later the landmark 1964 US Surgeon General's Report causally attributed lung cancer to cigarette smoking, ${ }^{3}$ and four decades after this the tobacco companies were defeated in the US court system on racketeering charges that they systematically deceived the public
\end{abstract}

in the pursuit of profits. The lesson from smoking in the 20th "cigarette" century is that it took decades to show that addictive, heavily marketed inhaled tobacco products caused lung disease. It is therefore imperative that the scientific community uses all available modalities to define the health effects of novel tobacco products so that public health policy can be based on evidence.

E-cigarettes use a metal resistance coil to heat and aerosolize mixtures of vegetable glycerin, propylene glycol, nicotine, and flavoring agents. E-liquids are conducted from a tank to the coil by a wick made of cotton, silica, or ceramic, and the user activates electric current through the coil by depressing a button or by generating airflow through the device. Since their introduction 15 years ago, e-cigarettes have undergone major changes in design that allow the user greater control over e-liquid composition, nicotine concentration, and how the e-liquid is aerosolized/vaped.

The health effects of exposure to e-cigarettes, especially of chronic exposure, are uncertain. However, e-cigarettes emit volatile carbonyls, reactive oxygen species, furans, and metals (nickel, lead, chromium), ${ }^{4}$ many of which are toxic to the lung. This review summarizes the rapidly expanding evidence from cell culture, animal, and human studies on the potential pulmonary health effects of e-cigarettes. 


\section{Sources and selection criteria}

We identified references for this review through searches of publications listed by PubMed from 1980 to 30 June 2019. Owing to the recent reports of severe lung injury associated with e-cigarette use, we also did an additional search in September 2019 and subsequently included several additional relevant studies published in September 2019, which were added during the proofing stage. We used the search terms "e-cigarette", "vape", "juul”, "lung", "airway", "respiratory", "cough", "methacholine", "nasal”, "alveolar", "alveoli", "immune”, "bronchial, "tracheal”, "bronchoalveolar", "nicotine", "propylene glycol”, "vegetable glycerin", "neutrophil”, "macrophage", "epithelia", "spirometry", and "FEV". We also identified references from relevant review articles. We included in vitro, animal, and human studies, including meta-analyses. Only articles published in English were reviewed. We screened more than 5000 articles of evidence classes I-IV and included classes I-III. We excluded articles published in non-peer reviewed journals and small uncontrolled series, with the exception of case reports of human lung disease associated with e-cigarette use. The final reference list was based on relevance to the topics covered in the review.

The tobacco industry has a long history of conducting studies intended to create doubt about the health effects of combustible tobacco and of misinterpreting data, and as tobacco companies consolidate their control of the $\$ 11.4 \mathrm{bn}$ (£9.3bn; €10.3) global e-cigarette market (projected to reach $\$ 86.4 \mathrm{bn}$ in 2025), ${ }^{5}$ traditional industry marketing, lobbying, and research strategies are increasingly apparent. Moreover, industry funding is strongly associated with finding no harm of e-cigarettes, compared with studies without a potential conflict of interest (odds ratio $67,95 \%$ confidence interval 8 to 553$).{ }^{6}$ We have included studies funded by the tobacco industry in our review, but we have identified them as such.

\section{Rates of e-cigarette use}

More than a billion people worldwide smoked tobacco in 2016. In the US, 34.3 million (14.0\%) adults ( $\geq 18$ years of age) were current smokers in 2017; 6.9 million $(2.8 \%)$ were current e-cigarette users. ${ }^{7}$ Rates of e-cigarette use are higher in young people and have accelerated recently. ${ }^{9}$ Among 8th, 10th, and 12th grade pupils in the Monitoring the Future study, for example, prevalence rates of vaping (e-cigarette use) in the US in 2018 were 9.7\%, 20\%, and 25\%, respectively. ${ }^{1011}$ Increases in 2018 in 10th and 12th grade pupils were the largest recorded for any substance in the 44 years that the study has tracked adolescent drug use.

\section{Device evolution and the rise of Juul}

E-cigarettes have undergone dramatic changes in design to deliver nicotine more efficiently. ${ }^{12-15}$ Initially, most sales came from "ciga-like" products that resembled traditional cigarettes. ${ }^{16}$ Modular systems (mods), containing batteries, fillable liquid tanks, and heating coils have a comparably small but loyal following. They allow the use of custom-made flavors and individualized settings for temperature and wattages. ${ }^{14}$

Newer pod devices, beginning with the Juul e-cigarette system, have seen a rapid rise in use in the US. Introduced in mid-2015, Juul had a dominant market position by 2018, accounting for more than $70 \%$ of US e-cigarette sales. ${ }^{16-18}$ During this time, overall US sales of e-cigarettes doubled, with Juul being responsible for the bulk of market growth. The Juul device resembles a USB memory stick with cartridges (pods) that are exchangeable by the user and filled with flavored e-liquids. Juul e-liquids contain nicotine in protonated form, generated by titration with benzoic acid to yield the nicotine benzoate salt. Users perceive aerosols produced from liquids containing nicotine salt as less irritating, allowing delivery of higher amounts of nicotine than in aerosols from traditional e-liquids that contain freebase nicotine. The nicotine concentration in US marketed Juul liquid cartridges (pods) is higher (5\% weight/weight; $59 \mathrm{mg} / \mathrm{mL} ; 127 \mathrm{mM}$ ) than in traditional e-liquids (typically $6-18 \mathrm{mg} /$ $\mathrm{mL}$ of nicotine; $37-111 \mathrm{mM}$ ). Recent studies have shown that Juul users have similar blood nicotine concentration profiles to users of combustible cigarettes. ${ }^{19}$

\section{Human studies \\ Studying lung toxicity}

The respiratory system varies dramatically in its composition and function from the large airways to the alveolar space. Proximally, the airways function to conduct air to the deeper lung while protecting it from injurious toxicants and microorganisms. To this end, they have a complex structure with cartilaginous elements anteriorly for structural support and a collapsing posterior wall to enable high airspeed velocity during coughing, nervous system innervation, a smooth muscle layer to facilitate bronchoconstriction, glands and surface epithelia that produce a mucous layer that hydrates the underlying epithelium and traps microbes, cilia that transport mucus away from the alveolar space, and extensive lymphatics. In contrast, the alveoli are delicate structures lined by thin alveolar type 1 epithelial cells and surfactant producing alveolar type 2 cells, along with alveolar macrophages. A single fused basement membrane separates the alveolar epithelium and capillary endothelium, yielding a remarkably thin alveolar-capillary barrier of approximately $5 \mu \mathrm{m}$ to facilitate gas diffusion. ${ }^{20}$ Given the vast differences between these two regions, toxicological investigations should focus on both the conducting airways and the alveolar spaces. Figure 1 shows the reported effects of vaping on the human pulmonary system.

\section{Population studies}

Users of e-cigarettes have reported several negative symptoms involving the nose, mouth, throat, and 
airways. $^{21}$ However, few epidemiologic studies have looked at chronic effects of e-cigarette use in either young people starting e-cigarettes or smokers transitioning to exclusive e-cigarette use.

Surveys of adolescents have found increased risk of respiratory symptoms. A survey of approximately 45000 adolescents in Hong Kong found that e-cigarette use in the previous month was associated with increased odds of reporting chronic cough or phlegm (odds ratio 2.1, 95\% confidence interval 1.8 to 2.5$).^{22}$ A study of almost 2000 high school students in Southern California, of whom nearly $10 \%$ were current (previous 30 days) e-cigarette users, reported that both past and current use were associated with a nearly twofold increase in the risk of chronic bronchitic symptoms (chronic cough, phlegm, or bronchitis), a finding that was robust to adjustments for sociodemographic confounders and cigarette use and was also observed in a sensitivity analysis restricted to those who had never used cigarettes. $^{23}$ A large survey of Korean high school students found that self reported diagnosis of asthma by a physician in the previous year was increased in current e-cigarette users compared with never users, after adjustment for exposure to cigarette smoke (odds ratio $2.7,1.3$ to 5.8 ). ${ }^{24}$
Other cross sectional surveys have also found associations of e-cigarette use with a history of asthma and with asthma exacerbations on the basis of state-wide surveys of young people in Hawaii and Florida. ${ }^{25-27}$ In adults, a recent analysis of data from the Behavioral Risk Factor Surveillance Survey found an association of e-cigarette use with asthma or chronic obstructive pulmonary disease (COPD), effects that were larger in non-smokers. ${ }^{28}$ In a population based study in Sweden, associations of e-cigarette use with respiratory symptoms (chronic cough, sputum, or wheeze) were strongest among dual users with cigarettes. ${ }^{29}$ Associations among non-smokers and never smokers were weaker and not statistically significant. Finally, a recent study of nearly 40000 participants in the Health eHeart Study found that e-cigarette use was associated with higher self ratings of dyspnea and reports of COPD and asthma. ${ }^{30}$ These studies were cross sectional, and outcomes were self reported. Prospective cohort studies are needed, but the consistency of these associations among both young and adult e-cigarette users suggest that e-cigarette users experience symptoms of both airway and alveolar injury, which are consistent with the studies of human and animal lungs, as discussed below.

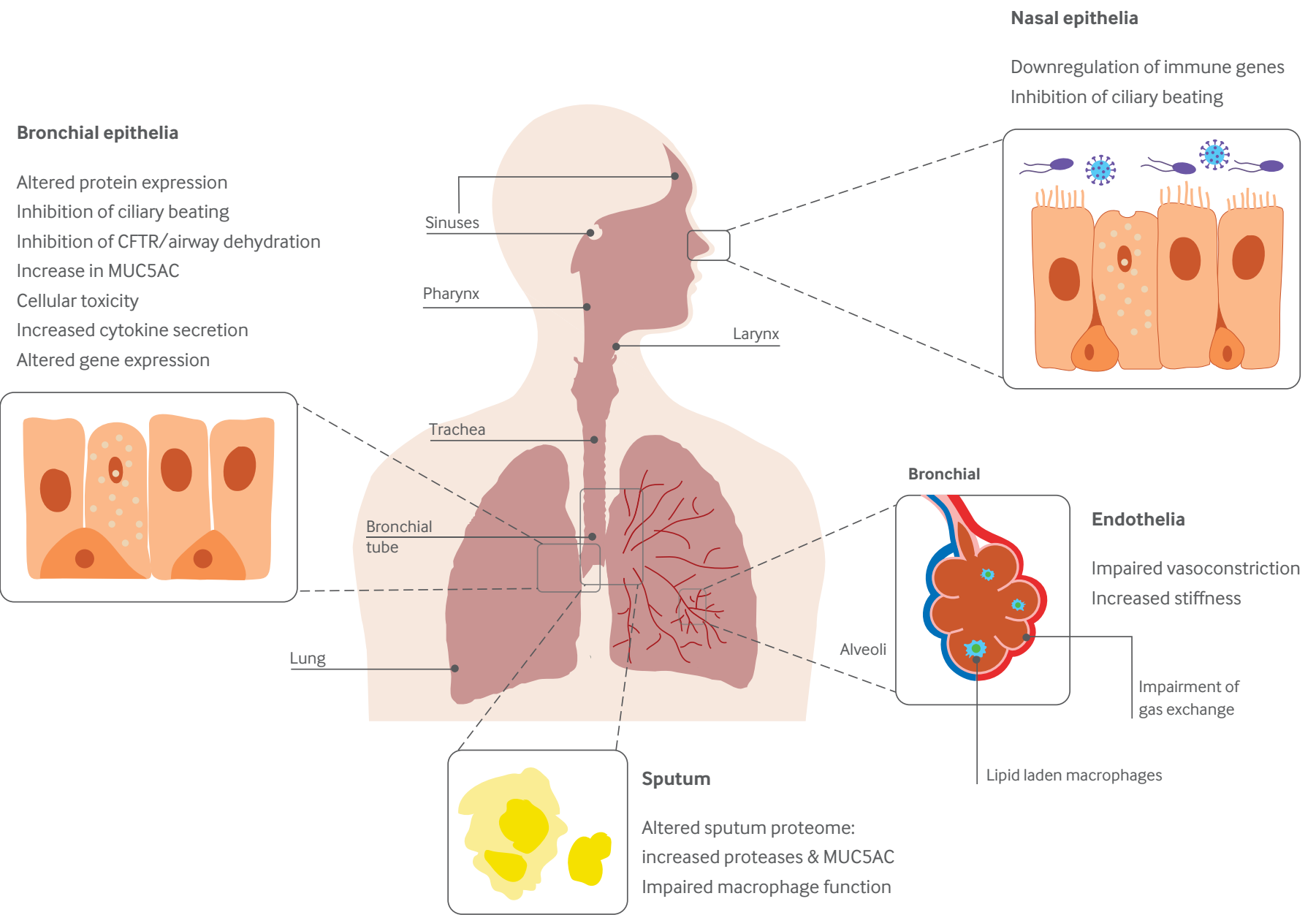

Fig 1 | Reported effects of vaping on the human pulmonary system 
In the summer of 2019, several hundred cases of acute respiratory illness associated with e-cigarette use were reported in the US, prompting multiple investigations by state and federal health agencies, including the Centers for Disease Control and Prevention (CDC). As of writing, seven deaths have been attributed to e-cigarette use, and investigations are ongoing. ${ }^{31}$ The clinical presentation of 53 affected vapers in Illinois and Wisconsin was recently described. ${ }^{32}$ Presenting symptoms included gastrointestinal (81\%), constitutional (100\%), and respiratory (98\%) symptoms, with $87 \%$ of patients reporting dyspnea and $83 \%$ reporting cough. Most patients had arterial hypoxemia (69\%), elevated blood neutrophil counts (94\%), and elevated transaminases (55\%). Fourteen patients underwent bronchoscopy with cellular analysis, showing an elevated median neutrophil percentage $(65 \%)$ and corresponding reduction in macrophage percentage (median $21 \%$ ). Seven bronchoalveolar lavage samples were stained with oil red $\mathrm{O}$ stain and showed lipid laden macrophages. Fifteen patients were diagnosed as having acute respiratory distress syndrome. and most patients showed abnormal chest radiography. All 48 patients scanned by computed tomography were found to have abnormal lung parenchyma, typically characterized by ground glass opacities in both lungs, sometimes with subpleural sparing. These findings have been monitored by the CDC, and similar findings have been reported in 25 states. ${ }^{33}$ Whether this novel "vaping associated respiratory syndrome" is caused by propylene glycol/vegetable glycerin and nicotine containing e-cigarettes, or is due to tetrahydrocannabinols and/or associated solvents and adulterants such as vitamin E, remains to be determined. ${ }^{34}$ However, similar cases have been found in the UK and Japan, suggesting that this has the potential to be a more widespread phenomenon, although the country to country variations in frequency remain to be determined. ${ }^{3536}$

\section{Studies of smokers who switch to e-cigarettes}

Several groups have studied symptom scores and spirometry among chronic smokers who transition to e-cigarette use. This is a useful design for assessing the respiratory effects of e-cigarettes; although some studies have found that e-cigarette users experience improvements in lung health, results have not been consistent even when users were able to reduce cigarette consumption. ${ }^{37-40}$ Studies funded by the tobacco industry have consistently found few adverse respiratory health outcomes in smokers transitioning to e-cigarette use..$^{41-43}$ An important caveat to these studies is that in general they have not looked at whether e-cigarettes have respiratory toxicity but at whether the measured outcomes differ from those of people exposed to ongoing cigarette smoke. To answer this question, studies would need to compare smokers who have transitioned to exclusive e-cigarette use with smokers who have quit without any intervention or with nicotine replacement therapy or approved pharmacotherapy, the current gold standard for treatment.

\section{Studies of spirometry}

Spirometry involves forced inhalation and exhalation maneuvers and the monitoring of airflow over time. This test is reproducible under optimal conditions (consistent patient effort with calibrated equipment), allowing assessment of airway obstruction and affording some insight into lung volumes. Importantly, it gives a limited window into lung function because it does not assess for restrictive lung physiology or gas exchange abnormalities and may change rapidly with exercise and other stimuli. For example, transient airway smooth muscle contraction, which can occur during exercise, is detectable during spirometry and can subsequently resolve within minutes to hours. The forced expiratory volume in one second $\left(\mathrm{FEV}_{1}\right)$ is considered to be a measure of air clearance from the large/cartilaginous airways, and reductions in $\mathrm{FEV}_{1}$ and/or the ratio of $\mathrm{FEV}_{1}$ to forced vital capacity $\left(\mathrm{FEV}_{1} / \mathrm{FVC}\right)$ may be due to smooth muscle contraction (as has been seen in animal studies) or may instead be a sign of more significant and long lasting structural lung damage.

Most spirometric studies of e-cigarette users have focused on acute changes in airflow immediately after a vaping session. These studies show mixed results, with some reporting evidence of airflow obstruction and others not. ${ }^{44-48}$ Notably, patients with pre-existing airway disease may be at higher risk of acute airway obstruction with e-cigarette exposure. ${ }^{49}$

Few longer term studies of e-cigarette use and spirometry after a period of abstinence have been performed. One study compared 30 healthy daily users of e-cigarettes (excluding current and former cigarette smokers) with 30 controls. ${ }^{50}$ The groups were matched for age, height, weight, ethnicity, and socioeconomic status; abstinence from vaping was required for at least one hour before testing. E-cigarette users were found to have lower $\mathrm{FEV}_{1}$ (4.6 (SD 0.7) L $v 5.2(0.8) \mathrm{L} ; \mathrm{P}=0.007)$ and $\mathrm{FEV}_{1} / \mathrm{FVC}$ (77.4 (7.2) v 83.4 (5.6); $\mathrm{P}=0.001$ ) compared with the control group, but spirometry was performed after a minimum of only one hour of abstinence, thus potentially reflecting acute bronchospasm rather than lasting changes in the airways. ${ }^{50}$ Smokers who have been studied after transitioning to e-cigarettes have been found to have either no change or slight improvements in spirometry. ${ }^{37} 39$ Importantly, the absence of short term changes in spirometry does not mean that e-cigarettes are harmless. Patients with cystic fibrosis, for example, are born with normal lungs but develop lung disease over time, and young ( $\sim$ year old) cystic fibrosis patients have normal $\mathrm{FEV}_{1}$, even though they have extensive chronic lung disease as measured by lung clearance index or by imaging. ${ }^{51}$ Similarly, changes in spirometry can reliably be detected only after years or decades of exposure to cigarette smoking, despite substantial 
injury to the distal lung that can be measured by other means. ${ }^{52}$ For example, significant pathologic changes, including small airway/alveolar destruction, have been observed in early stage smoking induced COPD by using imaging techniques, despite relatively mild changes to $\mathrm{FEV}_{1} \cdot{ }^{53}$

\section{Airway inflammation and injury}

Because of the delicate nature of the lungs, even mild inflammation can be damaging. ${ }^{54}$ Lung inflammation can be assessed histologically, by analysis of bronchoalveolar lavage, or by studying lung homogenates. Healthy e-cigarette users have been found to have erythematous and irritable airway mucosa, ${ }^{55}$ and cases of more serious bronchial injury have been reported. ${ }^{56}$ Increased levels of the MUC5AC mucin have been found both in bronchial epithelia and in airway secretions, although notably many of these e-cigarette users were former smokers. ${ }^{55} 57$ Increased mucin levels inversely correlate with the decline in lung function in COPD patients and are a biomarker of chronic bronchitis, indicating that mucins are a validated biomarker of harm. ${ }^{5859}$

Although increased exhaled nitric oxide may be suggestive of airway inflammation in asthma, exhaled nitric oxide can be decreased under conditions of high oxidative stress, as in COPD, making its interpretation less clear. ${ }^{60}$ Several groups have reported reductions in the fractional excretion of nitric oxide following exposure to e-cigarette aerosol. ${ }^{50}{ }^{61}$ Furthermore, proteomics of e-cigarette users' sputum has shown higher levels of neutrophil activation, including myeloperoxidase, neutrophil elastase, and proteinase-3. ${ }^{57}$ Increased protease concentrations have previously been observed in tobacco smokers' lungs, ${ }^{62-65}$ and the association between smoking, increased proteolysis, and lung damage is causal, suggesting that protease concentrations are another biomarker that may be useful for studying the effects of vaping on the lung. ${ }^{66-68}$ When dysregulated, lung proteases can degrade basement membranes and lead to emphysema, as seen in COPD patients. ${ }^{69}$ Increased proteolysis also causes bronchiectasis in cystic fibrosis and $\alpha 1$ anti-trypsin deficiency-type lung diseases, ${ }^{70} 71$ and it plays an important role in tumor progression/metastasis by facilitating tissue remodeling. ${ }^{72}$

Finally, a recent controlled study in healthy young occasional smokers and middle aged heavier smokers showed that just 15 minutes of exposure to aerosol from a $60 \mathrm{~W}$ e-cigarette impaired gas exchange and reduced expiratory gas flows, in association with increased blood concentrations of the lung specific protein CC16 that is secreted by club cells located near the terminal bronchioles. ${ }^{73}$ These results suggest that e-cigarettes may cause acute, physiologically detectable injury to the small airways.

\section{Alveolar inflammation and injury}

Given that cigarette smokers are at increased risk of life threatening alveolar injury and acute respiratory distress syndrome, ${ }^{7475}$ prioritizing further studies of possible subclinical alveolar injury from e-cigarettes will be important. A rapidly increasing number of case reports link e-cigarette use to severe inflammatory diseases affecting the small airways and alveoli: lipoid pneumonia, $^{76}$ eosinophilic pneumonia, ${ }^{77}$ diffuse alveolar hemorrhage, ${ }^{78}$ organizing pneumonia, ${ }^{77} 79$ respiratory bronchiolitis associated interstitial lung disease,,$^{80}$ and hypersensitivity pneumonitis. ${ }^{81}$

Hypersensitivity pneumonitis is caused by an inflammatory reaction against known inhalational antigens that commonly progresses to life threatening pulmonary fibrosis. One study exposed healthy volunteers with no history of cigarette or e-cigarette use to a single session of vaping. Analysis of blood samples showed increases in endothelial microparticles, which are shed from endothelia, suggesting that alveolar capillaries were activated or injured with this relatively mild exposure. ${ }^{46}$ Beyond this, comparatively little has been done to evaluate the effects of e-cigarette aerosol at the alveolar level in humans. Whether the case reports represent individual susceptibility, effects of the extraordinary diversity of flavors and other molecular products of e-cigarettes, or both is unknown. However, that e-cigarettes pose risks for hypersensitivity pneumonitis and other alveolar diseases at the population level is plausible.

\section{Effects on immunity}

Reporting of respiratory symptoms by e-cigarette users suggests increased susceptibility to and/ or delayed recovery from respiratory infections. A study of 30 healthy non-smokers exposed to e-cigarette aerosol found decreased cough sensitivity. ${ }^{82}$ If human ciliary dysfunction is also negatively affected, as suggested by animal and cellular studies, ${ }^{83}$ the combination of reduced coughing and impaired mucociliary clearance may predispose users to increased rates of pneumonia. Exposure to e-cigarettes may also broadly suppress important capacities of the innate immune system. Nasal scrape biopsies from non-smokers, smokers, and vapers showed extensive immunosuppression at the gene level with e-cigarette use. ${ }^{84}$ Healthy non-smokers were exposed to e-cigarette aerosol, and bronchoalveolar lavage was obtained to study alveolar macrophages. ${ }^{46}$ The expression of more than 60 genes was altered in e-cigarette users' alveolar macrophages two hours after just 20 puffs, including genes involved in inflammation. Neutrophil extracellular trap (NET) formation, or NETosis, is a mode of innate defense whereby neutrophils lyse DNA and release it into the extracellular environment to help to immobilize bacteria, a process that can also injure the lung. ${ }^{85}$ Neutrophils from chronic vapers have been found to have a greater propensity for NET formation than those from cigarette smokers or nonsmokers. ${ }^{57}$ Given that e-cigarettes may also impair neutrophil phagocytosis, ${ }^{86}$ these data suggest that neutrophil function may be impaired in e-cigarette users. 


\section{Animal studies}

Animal models provide a useful tool for studying the potential effects of exposure to e-cigarettes. The utility of animal models using intense exposure paradigms to shorten timescales and simplify experimental design was originally demonstrated conclusively in studies in mice identifying causal effects and mechanisms of oncogenesis induced by cigarette smoke. ${ }^{87-89}$ Approximately 60 such studies of effects of e-cigarettes have been performed in mice, with durations of exposure ranging from a single dose to three to six months using propylene glycol/ vegetable glycerin with or without nicotine and commercial e-liquids (table 1). Acute exposures have caused changes at the level of the protein, including up-regulation of mucins and cytokines, as well as cellular changes including impaired autophagy (table 1). Chronic e-cigarette exposures induce airway inflammation, neutrophilia, airway remodeling, and emphysema (table 1). Increased sensitivity to methacholine was also observed (table 1). Both nicotine dependent and nicotine independent effects were found. Although most studies found significant effects of vaping, two industry funded studies did not, ${ }^{103} 105$ consistent with the previously mentioned relation between industry funding and observed effects of vaping. ${ }^{6}$

Thus, vaping in mice leads to rapid changes at the cell and protein levels. Of greater concern, five to 16 weeks of e-cigarette exposure induced alveolar cell apoptosis and architectural simplification suggestive of emphysema, ${ }^{96106}$ although results have not been consistent. ${ }^{90} 107$ Finally, although e-cigarettes have been widely promoted as having a negligible risk of malignancy compared with smoked tobacco, exposure to e-cigarette aerosol has recently been associated with DNA damage, thought to occur via in situ metabolism of nicotine to nitrosamines. ${ }^{91}$

Two weeks of exposure to e-cigarette aerosol in mice decreased survival and increased pathogen load following inoculation with either Streptococcus pneumoniae or influenza $\mathrm{A}$, two leading causes of pneumonia in humans. ${ }^{97}$ Furthermore, the aerosol exposure may lead to enhanced upper airway colonization with pathogens and to virulent changes in pathogen phenotype, as shown with Staphylococcus aureus. ${ }^{98} 99$ Thus, although more studies are needed, the animal data suggesting that vaping leads to an increased susceptibility to infection would seem to correlate with the population level data in young adult humans, whereby vapers have increased rates of symptoms of chronic bronchitis. ${ }^{23}$

\section{In vitro studies of vaping}

\section{Methodological considerations}

Different exposure paradigms have been used to study e-cigarettes. Direct addition of e-liquids to in vitro systems does not replicate real world vaping. However, given that thousands of e-liquids are commercially available, it yields increased throughput. Condensing vaped e-liquids is an intermediate approach, although condensate can change over time and the effects of short lived

\begin{tabular}{|c|c|c|}
\hline Observation & Species & Duration of exposure (e-liquid) \\
\hline $\begin{array}{l}\text { Airway hyper-reactivity/ } \\
\text { bronchospasm } \\
90-93\end{array}$ & $\begin{array}{l}\text { Mice, guinea } \\
\text { pigs }\end{array}$ & $\begin{array}{l}\text { Acute (Old Kentucky e-liquid } 12 \mathrm{mg} / \mathrm{mL} \text { nicotine); } 6 \text { weeks, } 1 \mathrm{~h} / \text { day, } 5 \text { days/ } \\
\text { week (American Tobacco e-liquid, } \mathrm{PG} \text { and VG } \pm 12 \mathrm{mg} / \mathrm{mL} \text { nicotine); intratracheal } \\
\text { e-liquid instillation twice weekly for } 10 \text { weeks (Z-company e-liquid } 16 / \mathrm{mg} / \mathrm{mL} \\
\text { diluted } 50 \text { times in saline); } 3 \text { and } 28 \text { days (PG/VG or } \pm 18 \mathrm{mg} / \mathrm{mL} \text { nicotine or } \\
\text { American Tobacco e-liquid) }\end{array}$ \\
\hline $\begin{array}{l}\text { Increase in MUC5AC mucin or goblet cell } \\
\text { metaplasia }{ }^{559194}\end{array}$ & Mice, rats & $\begin{array}{l}\text { One } 3 \mathrm{~h} \text { exposure (PG/VG only); } 3 \text { and } 28 \text { days (PG/VG or } \pm 18 \mathrm{mg} / \mathrm{mL} \text { nicotine or } \\
\text { American Tobacco e-liquid); } 90 \text { days ( } P G / V G \pm 18 \mathrm{mg} / \mathrm{mL} \text { nicotine) }\end{array}$ \\
\hline Reduction in mucus clearance ${ }^{95}$ & Mice & 1-3 weeks, $20 \mathrm{~min} /$ day $(P G \pm 24 \mathrm{mg} / \mathrm{mL}$ nicotine) \\
\hline Increased inflammation ${ }^{9496-101}$ & Mice, rats & $\begin{array}{l}1 \mathrm{~h} / \text { day for } 4 \text { months (PG/VG } \pm 18-24 \mathrm{mg} / \mathrm{mL} \text { nicotine); one dose, lungs harvested } \\
0.5 \text { or } 24 \mathrm{~h} \text { later (commercial e-liquids with nicotine); } 1.5 \text { h, twice daily for } 2 \\
\text { weeks ( } \mathrm{NJOY} \text { menthol bold, } 1.8 \% \text { nicotine); } 3 \text { days, } 5 \mathrm{~h} / \text { day (Blu e-cig, classic } \\
\text { tobacco } 16 \mathrm{mg} / \mathrm{mL} \text { nicotine); } 1 \mathrm{~h} / \text { day, } 5 \text { days } / \text { week, for } 4 \text { weeks ( } 6-24 \mathrm{mg} / \mathrm{mL} \\
\text { commercial e-liquids); } 90 \text { days (PG/VG } \pm 18 \mathrm{mg} / \mathrm{mL} \text { nicotine) }\end{array}$ \\
\hline Increased PAFR expression ${ }^{8898}$ & Mice & $\begin{array}{l}\text { Twice daily intranasal dosing with e-liquid for } 4 \text { days ( } 24 \mathrm{mg} / \mathrm{mL} \text { nicotine } \\
\text { containing e-liquid) }\end{array}$ \\
\hline Nicotine dependent weight loss $s^{9093}$ & Mice, rats & $\begin{array}{l}6 \text { weeks, } 1 \mathrm{~h} / \text { day } 5 \text { days } / \text { week (American Tobacco e-liquid, } \mathrm{PG} \text { and } \mathrm{VG} \pm 12 \\
\mathrm{mg} / \mathrm{mL} \text { nicotine); intratracheal e-liquid instillation twice weekly for } 10 \text { weeks } \\
\text { (Z-company e-liquid } 16 / \mathrm{mg} / \mathrm{mL} \text { diluted } 50 \text { times in saline) }\end{array}$ \\
\hline $\begin{array}{l}\text { Impaired bacterial clearance and/or } \\
\text { altered virulence }{ }^{97-99}\end{array}$ & Mice & $\begin{array}{l}1 \mathrm{~h} / \text { day, } 5 \text { days/week, for } 4 \text { weeks ( } 6-24 \mathrm{mg} / \mathrm{mL} \text { commercial e-liquids); } 1.5 \mathrm{~h} \text {, } \\
\text { twice daily for } 2 \text { weeks (NJOY menthol bold, } 1.8 \% \text { nicotine) }\end{array}$ \\
\hline Oxidative stress ${ }^{97} 100$ & Mice & $\begin{array}{l}1.5 \mathrm{~h} \text {, twice daily for } 2 \text { weeks ( } \mathrm{NJOY} \text { menthol bold, } 1.8 \% \text { nicotine); } 3 \text { days, } 5 \mathrm{~h} / \text { day } \\
\text { (Blu e-cig, classic tobacco } 16 \mathrm{mg} / \mathrm{mL} \text { nicotine) }\end{array}$ \\
\hline $\begin{array}{l}\text { Impaired autophagy, increased } \\
\text { aggresome formation }{ }^{102}\end{array}$ & Mice & $3 \times 1 \mathrm{~h}$ exposure in $24 \mathrm{~h}(\mathrm{PG} / \mathrm{VG}$ and $25 \mathrm{mg} / \mathrm{mL}$ nicotine) \\
\hline Nasal squamous cell metaplasia ${ }^{103 \star}$ & Rats & 90 days, $6 \mathrm{~h} /$ day, 5 days $/$ week (PG/VG $\pm \leq 5 \mathrm{mg} / \mathrm{mL}$ nicotine) \\
\hline $\begin{array}{l}\text { DNA adducts found in lung, bladder } \\
\text { and heart; extrapulmonary effects }\end{array}$ & Mice & $1 \mathrm{~h} /$ day, 5 days/week, $3-6$ months (PG/VG $\pm 24 \mathrm{mg} / \mathrm{mL}$ nicotine) \\
\hline Emphysema $^{96}$ & Mice & $1 \mathrm{~h} /$ day for 4 months (PG/VG $\pm 18 \mathrm{mg} / \mathrm{mL}$ nicotine) \\
\hline Limited or no pulmonary effects ${ }^{103105 *}$ & Mice, rats & $\begin{array}{l}4 \mathrm{~h} / \text { day for } 1-3 \text { weeks (MarkTen } 250 \mu \mathrm{M} \text { nicotine); } 90 \text { days, } 6 \mathrm{~h} / \text { day, } 5 \text { days/week } \\
\text { (PG/VG } \pm \leq 5 \mathrm{mg} / \mathrm{mL} \text { nicotine) }\end{array}$ \\
\hline
\end{tabular}


reactive products may be missed. Direct exposure to e-liquid aerosol may be more relevant. However, unlike cigarette puff topographies that are well studied and for which standard dosing approaches have been recommended, ${ }^{108} \mathrm{e}$-cigarette topographies are not only poorly understood but are changing as new e-cigarette devices emerge. Owing to the lack of standards, dosimetry should be done to verify that aerosol is produced and reaching its target cells. E-liquids/vaping have been studied in vitro using a variety of cell culture systems and exposure models. Although immortalized cellular systems are useful for studying large numbers of e-liquids, we focus on vaping effects on primary pulmonary cells, as they have greater in vivo relevance.

\section{Airway epithelia}

Airway epithelia play important roles in sterilizing and humidifying inhaled air. They secrete ions/ water, mucins, and cytokines and clear mucus via ciliary beating. ${ }^{100}$ Exposure to tobacco smoke decreases ciliary beat frequency both in smokers and in vitro ${ }^{109-112}$ Ion transport is also impaired and mucin/cytokine secretion is elevated both in smokers and in vitro. ${ }^{101}$ Therefore, these cellular biomarkers of harm may be applicable to vaping studies. Acute exposure to e-cigarette vapor has been shown to rapidly decrease ciliary beating, inhibit mitochondrial function, and alter the expression of genes involved in oxidative and xenobiotic stress pathways (table 2), ${ }^{83} 115121$ mirroring changes at the protein level in bronchial epithelia obtained by bronchoscopy from vapers. ${ }^{55}$ Genes involved in ciliogenesis were also altered, which is consistent with the functional data showing impaired ciliary beating after vape exposure. ${ }^{83} 115$

Cystic fibrosis transmembrane conductance regulator (CFTR) is an apical membrane anion channel expressed in airway epithelia. Lack of functional CFTR causes cystic fibrosis lung disease. Acute and chronic cigarette smoke exposures rapidly inhibit CFTR function in smokers and in vitro. ${ }^{124-126}$ Similarly, e-cigarettes can also inhibit CFTR mediated $\mathrm{Cl}^{-}$ secretion and induce airway dehydration in airway epithelia. ${ }^{113}$ Failure of ciliary beating induced by e-cigarette aerosol could conflate this, contributing to a retention of mucus and bacteria, increasing the chance of developing lung disease (table 2). Whether vaping inhibits CFTR in vivo has yet to be ascertained; however, as CFTR function can be assessed using minimally invasive electrophysiologic approaches, measuring CFTR function may be a useful biomarker of harm that can be tested in the vaping population.

\section{Immune cells}

E-cigarette condensate induces alveolar macrophage apoptosis, increases pro-inflammatory cytokine secretion, and impairs phagocytosis. ${ }^{116}$ Similarly, direct e-liquid addition has been shown to impair macrophage phagocytosis. ${ }^{86}$ Neutrophils exposed to e-liquids have impaired phagocytosis, increased cytokine secretion, and increased NET release. ${ }^{86}$
Aerosol extract has been shown to cause morphologic changes in neutrophils, alter the expression of proinflammatory surface markers CD11b and CD66b, and increase the release of proteases and inflammatory cytokines. ${ }^{118}$ Secretion of these proteins, identified in the sputum of chronic e-cigarette users, ${ }^{57}$ would be predicted to increase neutrophil recruitment to the lung and increase degradation of collagen that could facilitate airway remodeling, lead to lung damage, or both. Importantly, whether the effects of e-cigarettes on neutrophils would be seen only in the lung or would extend to neutrophils in the pulmonary or extra-pulmonary blood supplies is not known. Certainly, although more studies on the effects of vaping on immune cells are needed, the in vitro studies seem to show that vaping can both activate immune cells and impair some of their key functions.

\section{Endothelia}

Studies have assessed the effects of e-cigarette exposureonthelung'smicrovasculature.E-cigarettes decreased the electrical resistance of endothelial cells derived from mice, rats, and humans, as well as exerting significant effects on cell viability that were associated with changes in cell signaling (activation of p38 MAPK). These changes are similar to those observed after exposure to cigarette smoke extract. $^{119}$

\section{Prokaryotes}

The airways are constantly exposed to both inhaled and oral bacteria. However, although the normal upper airways and oral cavity have measurable microbiomes, the distal airways are typically sterile owing to the ability to clear inhaled or aspirated bacteria. In cystic fibrosis and COPD, a lower airways microbiome develops. ${ }^{127} 128$ Few studies have looked at the effects of vaping on bacteria relevant to the lung, and none has investigated vapers' lung microbiomes. However, acute vaping in humans increased expression of platelet activating factor receptor, a receptor expressed in airway epithelia. ${ }^{98}$ Crucially, this receptor enables Streptococcus pneumoniae to adhere to mammalian cells, and, in vitro, vaping increased both platelet activating factor receptor expression and adherence of $S$ pneumoniae to airway epithelia. Similarly, chronic vaping was found to increase the virulence of Staphylococcus aureus and lead to increased biofilm formation. With chronic exposure to tobacco smoke, years are needed to alter the lower airways microbiome. Thus, a monitoring of vapers' lungs over a similar timeframe will likely be needed.

\section{Toxicity of specific aerosol components}

\section{Propylene glycol and vegetable glycerin}

As well as being a base constituent in e-liquids, propylene glycol is a common chemical used to produce polyester and as de-icer/antifreeze. Intravenous propylene glycol can cause acute renal and central nervous system toxicity. ${ }^{129}$ Propylene glycol 


\begin{tabular}{|c|c|c|c|}
\hline Observed effect & Cell type & E-liquids & Delivery methods \\
\hline $\begin{array}{l}\text { Airway surface dehydration } \\
\text { and/or inhibition of CFTR ion } \\
\text { transport }\end{array}$ & Human bronchial epithelia & $\begin{array}{l}\text { Red oak e-liquid, } 1 \% \text { nicotine; e-liquid } \\
\pm 36 \mathrm{mg} / \mathrm{mL} \text { nicotine }\end{array}$ & Aerosol delivery to cultures \\
\hline $\begin{array}{l}\text { Decreased ciliary } \\
\text { beating } 8396114115\end{array}$ & $\begin{array}{l}\text { Human bronchial and nasal } \\
\text { epithelia }\end{array}$ & $\begin{array}{l}\text { e-liquid } \pm 36 \mathrm{mg} / \mathrm{mL} \text { nicotine; e-liquid } \\
\pm 36 \mathrm{mg} / \mathrm{mL} \text { nicotine }\end{array}$ & Aerosol delivery to cultures \\
\hline $\begin{array}{l}\text { Increased MUC5AC mucin } \\
\text { production } 55\end{array}$ & Human bronchial epithelia & PG/VG (nicotine independent) & Aerosol delivery to cultures \\
\hline $\begin{array}{l}\text { Decreased cell viability/ } \\
\text { increased cellular } \\
\text { toxicity }^{86} 115-117\end{array}$ & $\begin{array}{l}\text { Human bronchial epithelia, } \\
\text { alveolar macrophages, } \\
\text { airway smooth muscle, NK } \\
\text { cells }\end{array}$ & $\begin{array}{l}\text { Several commercial e-liquids, all at } \\
12 \mathrm{mg} / \mathrm{mL} \text { nicotine; vaped e-liquid } \\
\text { condensate and/or aerosol from second } \\
\text { and third generation devices }\end{array}$ & $\begin{array}{l}\text { Liquid and aerosol delivery to } \\
\text { cultures }\end{array}$ \\
\hline $\begin{array}{l}\text { Increased cytokine } \\
\text { secretion }^{86118}\end{array}$ & $\begin{array}{l}\text { Human alveolar } \\
\text { macrophages, bronchial } \\
\text { epithelia, peripheral blood } \\
\text { neutrophils, NK cells }\end{array}$ & $\begin{array}{l}\text { Several flavored nicotine-free e-liquids; } \\
\text { commercial e-liquids } \pm 24 \mathrm{mg} / \mathrm{mL} \\
\text { nicotine }\end{array}$ & $\begin{array}{l}\text { Vaped e-liquid condensate from } \\
\text { third generation device }\end{array}$ \\
\hline Altered membrane fluidity ${ }^{55}$ & Human bronchial epithelia & PG/VG (nicotine independent) & $\begin{array}{l}\text { Aerosol and liquid delivery to } \\
\text { cultures }\end{array}$ \\
\hline $\begin{array}{l}\text { Decrease in barrier function } \\
\text { (resistance) }{ }^{119120}\end{array}$ & $\begin{array}{l}\text { Human, mouse, and rat } \\
\text { endothelia; human/COPD } \\
\text { bronchial epithelia }\end{array}$ & $\begin{array}{l}\text { Commercial e-liquids; up to } 25 \mathrm{mM} \\
\text { nicotine; USA tobacco flavor, } 24 \mathrm{mg} / \mathrm{mL} \\
\text { nicotine }\end{array}$ & Condensate generated \\
\hline Impaired phagocytosis 86116 & $\begin{array}{l}\text { Human alveolar } \\
\text { macrophages and peripheral } \\
\text { blood neutrophils }\end{array}$ & $\begin{array}{l}\text { Several flavored nicotine-free e-liquids; } \\
\text { commercial e-liquids } \pm 24 \mathrm{mg} / \mathrm{mL} \\
\text { nicotine }\end{array}$ & $\begin{array}{l}\text { Vaped e-liquid from third } \\
\text { generation device }\end{array}$ \\
\hline $\begin{array}{l}\text { Impaired mitochondrial function } \\
\text { and reduced glycolysis }{ }^{115}\end{array}$ & Human bronchial epithelia & Cinnamaldehyde flavored e-liquid & $\begin{array}{l}\text { Vaped e-liquid directly and } \\
\text { as condensate from third } \\
\text { generation device }\end{array}$ \\
\hline $\begin{array}{l}\text { p38 MAPK and/or ERK } \\
\text { activation }^{96118119}\end{array}$ & $\begin{array}{l}\text { Human bronchial epithelia; } \\
\text { human, mouse, and } \\
\text { rat endothelia; human } \\
\text { neutrophils }\end{array}$ & $\begin{array}{l}\text { e-liquid } \pm 36 \mathrm{mg} / \mathrm{mL} \text { nicotine; } \\
\text { commercial e-liquids; up to } 25 \mathrm{mM} \\
\text { nicotine; commercial e-liquids } \\
\pm 24 \mathrm{mg} / \mathrm{mL} \text { nicotine }\end{array}$ & $\begin{array}{l}\text { Aerosol delivery to cultures; } \\
\text { condensate generated using } \\
\text { second or third generation } \\
\text { devices }\end{array}$ \\
\hline $\begin{array}{l}\text { Induction of apoptosis and } \\
\text { necrosis }^{116}\end{array}$ & $\begin{array}{l}\text { Human alveolar } \\
\text { macrophages }\end{array}$ & $\begin{array}{l}\text { Commercial e-liquids } \pm 36 \mathrm{mg} / \mathrm{mL} \\
\text { nicotine }\end{array}$ & $\begin{array}{l}\text { Condensate generated using } \\
\text { second generation device }\end{array}$ \\
\hline Changes in gene expression ${ }^{121}$ & Human bronchial epithelia & VitroCell System & $\begin{array}{l}\text { Increased genes involved in } \\
\text { oxidative and xenobiotic stress } \\
\text { markers of ROS; decreased } \\
\text { genes involved in ciliary } \\
\text { function }\end{array}$ \\
\hline $\begin{array}{l}\text { No change in barrier function } \\
\text { (resistance), CBF, FOXJ1, MUCAC; } \\
\text { essentially no change in RNA } \\
\text { transcript expression }^{12{ }^{2} \star}\end{array}$ & Human bronchial epithelia & $\begin{array}{l}\text { "Blended tobacco" e-liquid } 18 \text { mg/mL } \\
\text { nicotine }\end{array}$ & $\begin{array}{l}\text { Vype E-pen; cells exposed } \\
\text { to vapor in BAT exposure } \\
\text { chambers }\end{array}$ \\
\hline $\begin{array}{l}\text { No effect on ASL height, ion } \\
\text { transport or } \mathrm{CBF}^{123 \star}\end{array}$ & Human bronchial epithelia & $\begin{array}{l}\text { Avail Vapor “Tobacco Row” } 18 \text { mg/mL } \\
\text { nicotine }\end{array}$ & $\begin{array}{l}\text { Aerosol generated using third } \\
\text { generation device }\end{array}$ \\
\hline
\end{tabular}

has previously been shown to inhibit renal glucose transport and corneal $\mathrm{Na}^{+} / \mathrm{K}^{+}$ATPase activity. ${ }^{130} 131$ Propylene glycol and vegetable glycerin are classified as "generally recognized as safe," if added in recommended amounts to food. However, this label does not apply to inhalational safety, and short term occupational exposures to propylene glycol caused irritation and either mild or no objective effects on pulmonary function, suggesting that propylene glycol may act as a sensory

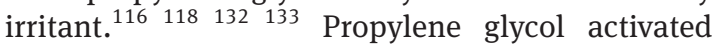
TRPV1 and TRPA1, two irritant receptors expressed in sensory nerves innervating the airways. ${ }^{134} 135$ These receptors promote asthmatic inflammation and airway hyper-reactivity in asthma models. ${ }^{136}$ MUC5AC protein concentrations were increased in the lungs of chronic vapers. ${ }^{57}$ Propylene glycol/ vegetable glycerin, and not nicotine, increased mucin expression after vaping in primary airway epithelia. ${ }^{57}$ Additional studies into their effects on pulmonary and immune cells are needed. Propylene glycol and vegetable glycerin can enter cells through several aquaporins including AQP3, which is expressed in the lung, suggesting that they may exert some effects intracellularly, ${ }^{137} 138139$ and vegetable glycerin can affect biologic membranes. ${ }^{140}$ Consistent with this, propylene glycol and vegetable glycerin decreased membrane fluidity in airway epithelia. ${ }^{55}$ Decreases in membrane fluidity may affect endocytosis (including phagocytosis, a specialized form of endocytosis), exocytosis, and plasma membrane protein-protein interactions. "The dose and the route make the poison" is a founding principle of toxicology, and high doses of inhaled propylene glycol/vegetable glycerin, which may occur during chronic vaping, likely contribute to the nicotine independent effects that have been described. Therefore, the safety of propylene glycol and vegetable glycerin at levels inhaled by e-cigarette users remains uncertain. 


\section{Nicotine}

Nicotinic acetylcholine receptors (nAChR) are ligand gated ion channels expressed in the airways. ${ }^{141-144}$ nAChR activation increases cytosolic $\mathrm{Ca}^{2+}$ levels and can inhibit CFTR in airway epithelia. ${ }^{145}$ Nicotine can also affect alveolar macrophages. ${ }^{116}$ Protease and interleukin 8 secretion from neutrophils is also independent of nicotine. Furthermore, inhaled nicotine increases elastase gene expression in neutrophils. ${ }^{146147}$ However, the effects of nicotine can be extensive and varied, as described elsewhere. ${ }^{148}$

nAChRs can regulate cell proliferation and inhibit apoptosis, ${ }^{149}$ and uncontrolled cell proliferation is a hallmark of cancer. In genome-wide association studies, $\alpha 3, \alpha 5$, and $\beta 4 \mathrm{nAChR}$ were associated with lung cancer. ${ }^{150-153}$ Additionally, differential $\mathrm{nAChR}$ expression profiles between non-smokers and smokers with non-small cell lung cancer were observed. ${ }^{154}$ Whether chronic activation of nAChR to nicotine via e-cigarettes can cause lung cancer is unknown, but the role of nAChR $\alpha 7$ in contributing to non-small cell lung cancer by altering cell proliferation and apoptotic resistance has been reported..$^{154} 155$ Nicotine contributes to vascular endothelial dysfunction by increasing leakiness. ${ }^{156}$ Furthermore, exposure to nicotine, but not propylene glycol/vegetable glycerin, increased arterial stiffness and adversely affected the microcirculation, ${ }^{157}$ suggesting that nicotine delivered by e-cigarettes may be a risk factor for cardiovascular disease. Nicotine exposure from e-cigarettes will likely have pharmacologic effects in any organ where nAChR are expressed. Thus, e-cigarette use may affect inflammation in the airways that could alter susceptibility to infection and/or increase the risk of developing COPD or lung cancer.

\section{Flavors}

E-liquids contain many flavors including aldehydes (vanillin, vanilla; benzaldehyde, berry/fruit; cinnamaldehyde, cinnamon; damascenone, tobacco), benzyl alcohol, terpenes (linalool, flowery; farnesol, apple), pyrazines (coffee, chocolate), menthol, menthone and other minty compounds, and sweet flavors including ethyl maltol. The combination of these and many other chemicals gives rise to the thousands of marketed flavored e-liquids. Many flavors are used as food additives and scents in cosmetics. However, their safety in the lung, at levels inhaled by e-cigarette users, is uncertain. ${ }^{158}$ Whereas occupational exposures to these flavors are regulated, concentrations in e-cigarettes are not. ${ }^{159}$ This is of concern as aldehyde flavors can be hazardous at elevated concentrations. However, as with nicotine, the flavor concentrations seen in the lungs during vaping are unknown.

An in vitro study assessed about 150 e-liquids and found a positive correlation between the number of flavors in an e-liquid and its in vitro toxicity. ${ }^{117}$ It also found that the concentrations of vanillin and cinnamaldehyde in different e-liquids correlated with overall toxicity. Concentrations of cinnamaldehyde in e-liquids can exceed $1 \mathrm{M}$ (molar), and cinnamaldehyde flavored e-cigarette aerosols caused cytotoxicity and ciliary dysfunction in epithelia and inflammation in vivo. ${ }^{115} 160-163$ Great concern has been expressed about the presence of the buttery flavor diacetyl in e-liquids, owing to its known pulmonary toxicity and propensity for causing bronchiolitis obliterans. ${ }^{158} 159163164$ Intriguingly, within hours after mixing, aldehyde flavors can undergo chemical reactions with propylene glycol/ vegetable glycerin, forming acetal compounds. These compounds, which are stable in aqueous environments at physiologic $\mathrm{pH}$, as an aerosol can activate irritant receptors. ${ }^{165}$ Thus, e-liquids are much more complex than initially thought and are chemically unstable, forming compounds with novel respiratory toxicological effects.

\section{Degradation products (eg, aldehydes)}

Initial studies reported that formaldehyde was formed during the vaping process under high heat conditions. ${ }^{166}$ Although some of the more recent e-cigarette devices limit temperature in an attempt to minimize this, multiple reports have documented the formation of acetaldehyde, acrolein, diacetyl, and formaldehyde under a wide range of conditions. ${ }^{167}$ 168 Intermediate products including glycidol and acetol have also been detected, suggesting that these carbonyls are likely produced from heated propylene glycol/vegetable glycerin through oxidation. ${ }^{169}$ Glycidol, an epoxide, is an irritant and tightly controlled known carcinogen, and acrolein is a potent irritant and the major non-cancer hazard in tobacco smoke, ${ }^{170}{ }^{171}$ suggesting that these degradation products are relevant to lung health.

\section{Effects on population health}

In the US, the Food and Drug Administration (FDA) is required to consider the net effects of regulatory policy on population health. Although a full review of this topic is beyond the scope of this review, recent assessments have come to different conclusions about whether possible harm reduction benefits of substituting e-cigarette for cigarettes could outweigh adverse effects of e-cigarettes among never smokers, ex-smokers continuing to use e-cigarettes, and dual users of cigarettes and e-cigarettes. ${ }^{172} 173$ These inconsistent conclusions reflect uncertainty about the long term health effects of e-cigarettes, their effectiveness as smoking cessation agents, and their effect on children. A modest increase in risk of e-cigarette attributable respiratory diseases such as lung cancer or COPD, or cardiovascular disease, could markedly shift the net evidence base on population effects to support more restrictive regulatory policy on e-cigarettes. Effects of other little studied outcomes of e-cigarette exposure, including in utero exposure to maternal e-cigarette use and secondhand exposure to e-cigarette aerosol in bystanders, could also shift the assessment of respiratory and other population effects. ${ }^{174} 175$ In the US, the assessment of effects may change on the basis 
Box $1 \mid$ Challenges in the study of novel tobacco products/e-cigarettes

- Rapid introduction of new devices (Heat-Not-Burn/IQOS)

- Minimal information from vendors about e-liquid content

- Rapid evolution of existing e-cigarette technology-devices may be obsolete by the time a study is finished and published

- Lack of a standard “e-cigarette liquid/device” vis à vis “Kentucky Research cigarettes”

- Lack of standardization for e-cigarette aerosol generation and exposure

- Variability in operating parameters for devices (power, ambient conditions)

- Dual use of combustible cigarettes with other tobacco products including e-cigarettes, hookah, and marijuana

- Different devices across different countries and regulatory domains-for example, Juul contains $59 \mathrm{mg} / \mathrm{mL}$ nicotine in the US and $18 \mathrm{mg} / \mathrm{mL}$ in the UK

- Ethical considerations make study of addictive and potentially harmful liquids/devices in never-smokers challenging

- Many of the important outcomes related to chronic toxicity (for example, chronic obstructive pulmonary disease) take many years to develop, so the true effects may not be known for decades

- The effect on vulnerable populations (such as people with asthma, chronic obstructive pulmonary disease, and/or lung cancer) may differ from the effects seen in young healthy normal people recent European Respiratory Society panel concluded that as the chronic effects of e-cigarette use are unknown, no evidence shows that they are safer than other tobacco products and that, on the basis of current knowledge, negative health effects cannot be excluded.

\section{Challenges and guidelines for clinicians}

Although several large and influential organizations have published official statements and guidelines pertaining to the use of e-cigarettes, ${ }^{4} 183190$ device technology and corresponding patterns of use are rapidly changing, and research continues to advance our understanding of health effects. Therefore, these recommendations can quickly become dated (box 1). For example, the addictive potential of nicotine salts may have contributed to the dramatic recent increase in 2018 in vaping among young people in the US, fueled by Juul. However, this addictive potential may be more satisfying to smokers who are switching to e-cigarettes. ${ }^{19}$ We note, however, that whereas Juul are currently sold with $59 \mathrm{mg} / \mathrm{mL}$ of nicotine salt in the US, they can be sold only with $18 \mathrm{mg} / \mathrm{mL}$ in the UK. Thus, we speculate that this may influence their relative popularity on either side of the Atlantic and/ or influence their addictiveness versus success in smoking cessation.

The uncertainty about the health risks of e-cigarettes and their efficacy as smoking cessation agents poses a challenge to clinicians, as smokers are using e-cigarettes in attempts to quit smoking and they look to their physicians for guidance. The use of evidence based pharmacotherapy and nicotine patches that are safe and effective in reducing the dependence on nicotine in cigarettes, combined with counseling, is the only approach for which little therapeutic or health uncertainty exists (fig 2). ${ }^{191}$ A supportive environment including counseling has been key to the success of this approach, and smokers should be encouraged to take advantage of complementary community and therapeutic resources. Smokers and ex-smokers using e-cigarettes should be provided with clear information on the uncertainties about health risks and harm reduction and encouraged to participate in complementary counseling using established approaches with a goal of quitting all tobacco products and ultimately reducing nicotine dependency as soon as possible. Smokers should, in particular, be cautioned about the hazards of dual cigarette and e-cigarette use, which may impede quit attempts, and the recently discovered potential risks of switching to e-cigarettes.

Pediatricians are faced with an epidemic of e-cigarette use for which there is arguably no benefit and potentially substantial, albeit uncertain, health risk. ${ }^{192}$ Communication of this risk to young people and parents is a key service that pediatricians can provide. For young people, prevention is key, and clinicians should recommend evidence based treatment for those using tobacco products. ${ }^{5}$ Because the community and policy makers look to physicians for information on children's health, the 


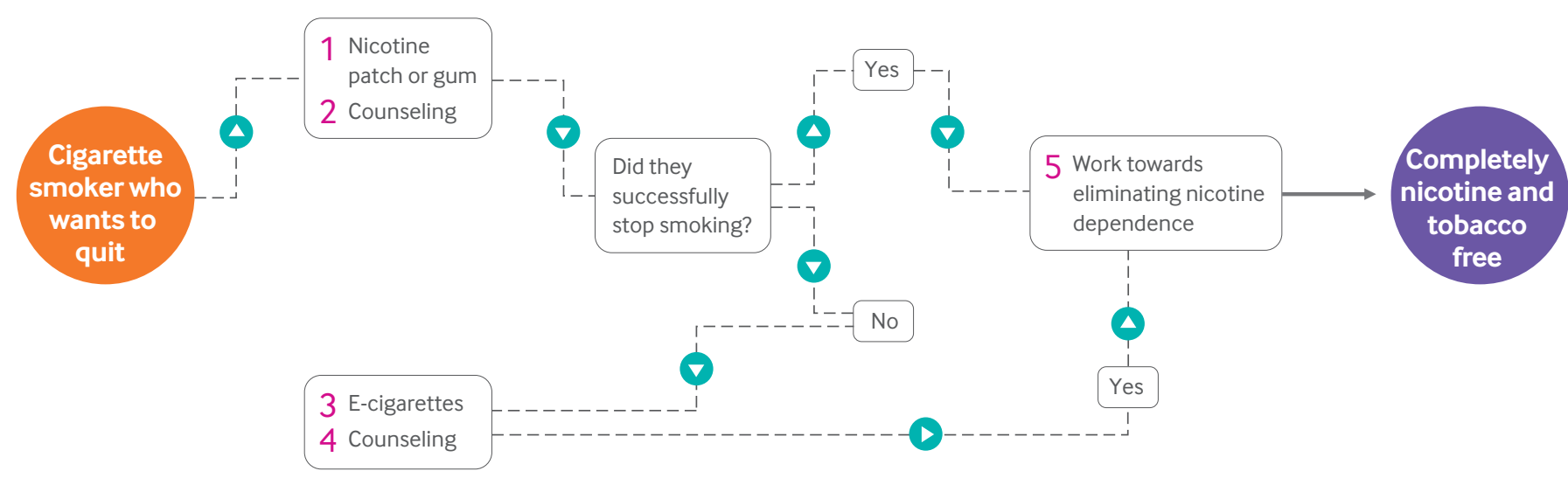

Fig 2 | Flowchart outlining proposed smoking cessation regimen that espouses counseling and nicotine cessation. Given the potential health risks associated with vaping, tobacco smokers looking to quit should first try nicotine patch or gum along with counseling $(1,2)$. If this approach fails, e-cigarettes could be used as a second attempt $(3,4)$. Given that nicotine is not risk-free, attempts should then be made to end nicotine dependence (5). As nicotine levels in e-liquids differ globally, the use of e-cigarettes as a smoking/nicotine cessation device may be more effective in countries with lower nicotine levels

pediatrician has a unique opportunity to promote action, including enforcement of age, sales, and marketing limitations, raising the legal age limit for tobacco use to 21 , and innovative regulation such as banning flavored tobacco products and other public health action.

\section{How to perform long term toxicology studies to assess the effects of e-liquids?}

Even though e-cigarettes contain strongly psychoactive substances (nicotine or nicotine salt), they do not require rigorous testing before being marketed. In contrast, for a new pharmaceutical product to reach the market requires a well defined approach that includes preclinical toxicology in animal models followed by robust clinical trials. ${ }^{193}$ We propose that e-cigarettes be similarly regulated and evaluated in a well defined and transparent series of preclinical, time appropriate animal models. Although conducting preclinical toxicological studies in animals is fairly straightforward, doing "clinical trial” type studies in humans leads to interesting ethical considerations. Administering e-cigarettes to healthy non-smokers would be unethical. However, given that many current smokers are in the process of developing lung pathology and e-cigarette users' lungs also seem to be undergoing changes, will conducting clinical trials in current smokers be appropriately informative? Using rigorous and transparent preclinical studies

\section{RESEARCH QUESTIONS}

- Does inhaled nicotine cause direct pulmonary toxicity?

-What is the significance of lipid laden macrophages in e-cigarette associated lung disease?

- Do e-cigarettes have detrimental effects on adolescent lung development?

- What is the effect of vaping on vulnerable populations (those with pre-existing conditions such as asthma or chronic obstructive pulmonary disease)?

- Does e-cigarette use lead to immunosuppression? to inform both vendors and the general public as to the relative effects of different e-liquids by using the same approach used for potential therapeutics would be a step forward. Certainly, given that vaping is now a multibillion dollar industry, the e-cigarette companies would seem to have the means to support these studies.

\section{Conclusions}

We reiterate that, to date, no long term vaping toxicological/safety studies have been done in humans; without these data, saying with certainty that e-cigarettes are safer than combustible cigarettes is impossible. Box 1 outlines the challenges facing the field. Given the survey data showing increased symptoms of respiratory disease and the many lines of human, animal, and in vitro experimental evidence that e-cigarette aerosol can negatively affect multiple aspects of lung cellular and organ physiology and immune function, e-cigarettes will likely prove to have at least some pulmonary toxicity with chronic and possibly even short term use. Several important principles will determine how lung disease manifests and how severely: as with smokers, vapers are likely to have variable susceptibility to lung injury, influenced by many interacting genetic and environmental factors; certain variations of e-cigarette technology (atomizer construction, coil power, nicotine exposure, and flavorants) will prove more harmful than others; dual use with combustible cigarettes, the dominant adult use pattern, may potentiate toxicity; a critical factor will be the extent to which vaping alters the susceptibility to and trajectory of bacterial and viral lung infections; and the continued rapid technological evolution of these devices may mitigate or potentiate particular toxicities.

We thank our colleagues at Duke, UCSF, UNC, USC, Yale, and elsewhere for insightful comments on e-cigarettes and vaping. Contributors: All the authors jointly conceived of, researched, and wrote this article. 
Funding: This work was funded by NIH/FDA HL120100 and NIH/ NHLBI R01 HL135642 (RT), U54DA036151 and R01ES029435 (SE)), NHLBI U54 HL147127 (JG), and NIH/FDA P50CA180905 and NIH/ NICHD R21HD084812 (RM). Research reported in this publication was in part supported by NIH and the FDA Center for Tobacco Products (CTP). The content is solely the responsibility of the authors and does not necessarily represent the official views of the $\mathrm{NIH}$ or the Food and Drug Administration.

Competing interests: We have read and understood the BMJ policy on the declaration of interests and declare that we have no conflicts of interest; SEJ has receiving personal fees from Hydra Biosciences LLC and Sanofi SA and non-financial support from GlaxoSmithKline Pharmaceuticals outside the submitted work.

Provenance and peer review: Commissioned; externally peer reviewed.

Patient involvement: No patients were involved in the drafting or review of this manuscript.

This is an Open Access article distributed in accordance with the terms of the Creative Commons Attribution (CC BY 4.0) license, which permits others to distribute, remix, adapt and build upon this work, for commercial use, provided the original work is properly cited. See: http://creativecommons.org/licenses/by/4.0/.

1 US Department of Health and Human Services. The Health Consequences of Smoking-50 Years of Progress: A Report of the Surgeon General . US Department of Health and Human Services, Centers for Disease Control and Prevention, National Center for Chronic Disease Prevention and Health Promotion, Office on Smoking and Health, 2014

2 Ochsner A, Debakey M. Primary pulmonary malignancy: treatment by total pneumonectomy; analysis of 79 collected cases and presentation of 7 personal cases. Ochsner / 1999;1:109-25.

3 US Department of Health. Education, and Welfare. Smoking and Health: Report of the Advisory Committee to the Surgeon General of the Public Health Service. Public Health Service Publication No 1103. 1964. https://profiles.nlm.nih.gov/ps/retrieve/ResourceMetadata/ NNBCXB.

4 Eaton DL, Kwan LY, Stratton K, eds. Public Health Consequences of E-Cigarettes . National Academies Press, 2018

5 Walley SC, Wilson KM, Winickoff IP, Groner I. A Public Health Crisis: Electronic Cigarettes, Vape, and JUUL. Pediatrics 2019;143:e20182741. doi:10.1542/peds.2018-2741

6 Pisinger C, Godtfredsen N, Bender AM. A conflict of interest is strongly associated with tobacco industry-favourable results, indicating no harm of e-cigarettes. Prev Med 2019;119:124-31. doi:10.1016/j. ypmed.2018.12.011

7 Ahluwalia IB, Smith T, Arrazola RA, et al. Current Tobacco Smoking, Quit Attempts, and Knowledge About Smoking Risks Among Persons Aged $\geq 15$ Years - Global Adult Tobacco Survey, 28 Countries, 2008-2016. MMWR Morb Mortal Wkly Rep 2018;67:1072-6. doi:10.15585/mmwr.mm6738a7

8 Wang TW, Asman K, Gentzke AS, et al. Tobacco Product Use Among Adults - United States, 2017. MMWR Morb Mortal Wkly Rep 2018;67:1225-32. doi:10.15585/mmwr.mm6744a2

9 Gottlieb MA. Regulation of E-Cigarettes in the United States and Its Role in a Youth Epidemic. Children (Basel) 2019;6:E40. doi:10.3390/children6030040

10 Patrick ME, O'Malley PM, Kloska DD, et al. Novel psychoactive substance use by US adolescents: Characteristics associated with use of synthetic cannabinoids and synthetic cathinones. Drug Alcohol Rev 2016;35:586-90. doi:10.1111/dar.12372

11 Miech R, Johnston L, O'Malley PM, Bachman JG, Patrick ME. Adolescent Vaping and Nicotine Use in 2017-2018 - U.S. National Estimates. N Engl J Med 2019;380:192-3. doi:10.1056/NEJMc1814130

12 Barrington-Trimis JL, Gibson LA, Halpern-Felsher B, et al. Type of E-Cigarette Device Used Among Adolescents and Young Adults: Findings From a Pooled Analysis of Eight Studies of 2166 Vapers. Nicotine Tob Res 2018;20:271-4. doi:10.1093/ntr/ntx069

13 Hsu G, Sun JY, Zhu SH. Evolution of Electronic Cigarette Brands From 2013-2014 to 2016-2017: Analysis of Brand Websites. J Med Internet Res 2018;20:e80. doi:10.2196/jmir.8550

14 Pearson JL, Reed DM, Villanti AC. Vapes, e-cigs, and mods: what do young adults call e-cigarettes?Nicotine Tob Res 2018. doi:10.1093/ ntr/nty223

15 Galstyan E, Galimov A, Sussman S. Commentary: The Emergence of Pod Mods at Vape Shops. Eval Health Prof 2019;42:118-24. doi:10.1177/0163278718812976

16 King BA, Gammon DG, Marynak KL, Rogers T. Electronic Cigarette Sales in the United States, 2013-2017. JAMA 2018;320:1379-80. doi:10.1001/jama.2018.10488

17 Cullen KA, Ambrose BK, Gentzke AS, Apelberg BJ, Jamal A, King BA. Notes from the Field: Use of Electronic Cigarettes and Any Tobacco
Product Among Middle and High School Students - United States, 2011-2018. MMWR Morb Mortal Wkly Rep 2018;67:1276-7. doi:10.15585/mmwr.mm6745a5

18 Huang J, Duan Z, Kwok J, et al. Vaping versus JUULing: how the extraordinary growth and marketing of JUUL transformed the US retail e-cigarette market. Tob Control 2019:28:146-51. doi:10.1136/ tobaccocontrol-2018-054382

19 Jackler RK, Ramamurthi D. Nicotine arms race: JUUL and the high-nicotine product market. Tob Control 2019;tobaccocontrol-2018-054796. doi:10.1136/tobaccocontrol-2018-054796

20 Tsunoda S, Fukaya H, Sugihara T, Martin CJ, Hildebrandt J. Lung volume, thickness of alveolar walls, and microscopic anisotropy of expansion. Respir Physiol 1974:22:285-96. doi:10.1016/00345687(74)90078-4

21 Hua M, Alfi M, Talbot P. Health-related effects reported by electronic cigarette users in online forums. J Med Internet Res 2013;15:e59. doi:10.2196/jmir.2324

22 Wang MP, Ho SY, Leung LT, Lam TH. Electronic Cigarette Use and Respiratory Symptoms in Chinese Adolescents in Hong Kong. JAMA Pediatr 2016:170:89-91. doi:10.1001/jamapediatrics.2015.3024

23 McConnell R, Barrington-Trimis JL, Wang K, et al. Electronic Cigarette Use and Respiratory Symptoms in Adolescents. Am I Respir Crit Care Med 2017:195:1043-9. doi:10.1164/rccm.201604-08040C

24 Cho JH, Paik SY. Association between Electronic Cigarette Use and Asthma among High School Students in South Korea. PLOS One 2016:11:e0151022. doi:10.1371/journal.pone.0151022

25 Schweitzer RJ, Wills TA, Tam E, Pagano I, Choi K. E-cigarette use and asthma in a multiethnic sample of adolescents. Prev Med 2017:105:226-31. doi:10.1016/i.ypmed.2017.09.023

26 Choi K, Bernat D. E-Cigarette Use Among Florida Youth With and Without Asthma. Am J Prev Med 2016;51:446-53. doi:10.1016/j. amepre.2016.03.010

27 Reid KM, Forrest JR, Porter L. Tobacco Product Use Among Youths With and Without Lifetime Asthma - Florida, 2016. MMWR Morb Mortal Wkly Rep 2018;67:599-601. doi:10.15585/mmwr. mm6721a2

28 Wills TA, Pagano I, Williams RJ, Tam EK. E-cigarette use and respiratory disorder in an adult sample. Drug Alcohol Depend 2019;194:36370. doi:10.1016/i.drugalcdep.2018.10.004

29 Hedman L, Backman H, Stridsman C, et al. Association of Electronic Cigarette Use With Smoking Habits, Demographic Factors, and Respiratory Symptoms. JAMA Netw Open 2018;1:e180789. doi:10.1001/jamanetworkopen.2018.0789

30 Wang JB, Olgin JE, Nah G, et al. Cigarette and e-cigarette dual use and risk of cardiopulmonary symptoms in the Health eHeart Study. PLoS One 2018;13:e0198681. doi:10.1371/journal.pone.0198681

31 Centers for Disease Control and Prevention. Outbreak of Lung Injury Associated with E-Cigarette Use, or Vaping. 2019. https://www.cdc. gov/tobacco/basic_information/e-cigarettes/severe-lung-disease. html.

32 Layden JE, Ghinai I, Pray I, et al. Pulmonary Illness Related to E-Cigarette Use in Illinois and Wisconsin - Preliminary Report. N Engl I Med 2019 doi:10.1056/NEJMoa1911614

33 Centers for Disease Control and Prevention. Severe Pulmonary Disease Associated with Electronic-Cigarette-Product Use - Interim Guidance. 2019. https://www.cdc.gov/mmwr/volumes/68/wr/ mm6836e2.htm?s_cid=mm6836e2_e\&deliveryName=USCDC_921 DM8850.

34 Hammond D. Outbreak of pulmonary diseases linked to vaping. BMJ 2019:366:15445. doi:10.1136/bmj.15445

35 Itoh M, Aoshiba K, Herai Y, Nakamura H, Takemura T. Lung injury associated with electronic cigarettes inhalation diagnosed by transbronchial lung biopsy. Respirol Case Rep 2017;6:e00282. doi:10.1002/rcr2.282

36 Viswam D, Trotter S, Burge PS, Walters GI. Respiratory failure caused by lipoid pneumonia from vaping e-cigarettes. BMJ Case Rep 2018;2018:bcr-2018-224350. doi:10.1136/bcr-2018224350

37 Cibella F, Campagna D, Caponnetto P, et al. Lung function and respiratory symptoms in a randomized smoking cessation trial of electronic cigarettes. Clin Sci (Lond) 2016;130:1929-37. doi:10.1042/CS20160268

38 Polosa R, Moriaria IB, Caponnetto P, et al. Persisting long term benefits of smoking abstinence and reduction in asthmatic smokers who have switched to electronic cigarettes. Discov Med 2016;21:99 108.

39 Veldheer S, Yingst J, Midya V, et al. Pulmonary and other health effects of electronic cigarette use among adult smokers participating in a randomized controlled smoking reduction trial. Addict Behav 2019.91.95-101 doi:10.1016/i.addbeh.2018.10.041

40 Hajek P, Phillips-Waller A, Przulj D, et al. A Randomized Trial of E-Cigarettes versus Nicotine-Replacement Therapy. N Engl J Med 2019;380:629-37. doi:10.1056/NEJMoa1808779

41 Walele T, Bush J, Koch A, Savioz R, Martin C, O'Connell G. Evaluation of the safety profile of an electronic vapour product 
used for two years by smokers in a real-life setting. Regul Toxicol Pharmacol 2018;92:226-38. doi:10.1016/j.yrtph.2017.12.010

42 D’Ruiz CD, O'Connell G, Graff DW, Yan XS. Measurement of cardiovascular and pulmonary function endpoints and other physiological effects following partial or complete substitution of cigarettes with electronic cigarettes in adult smokers. Regul Toxicol Pharmacol 2017;87:36-53. doi:10.1016/j.yrtph.2017.05.002

43 Cravo AS, Bush J, Sharma G, et al. A randomised, parallel group study to evaluate the safety profile of an electronic vapour product over 12 weeks. Regul Toxicol Pharmacol 2016;81(Suppl 1):S1-14 doi:10.1016/j.yrtph.2016.10.003

44 Vardavas Cl, Anagnostopoulos N, Kougias M, Evangelopoulou V, Connolly GN, Behrakis PK. Short-term pulmonary effects of using an electronic cigarette: impact on respiratory flow resistance, impedance, and exhaled nitric oxide. Chest 2012;141:1400-6. doi:10.1378/chest.11-2443

45 Flouris AD, Chorti MS, Poulianiti KP, et al. Acute impact of active and passive electronic cigarette smoking on serum cotinine and lung function. Inhal Toxicol 2013;25:91-101. doi:10.3109/08958378.2 012.758197

46 Staudt MR, Salit J, Kaner RJ, Hollmann C, Crystal RG. Altered lung biology of healthy never smokers following acute inhalation of E-cigarettes. Respir Res 2018;19:78. doi:10.1186/s12931-0180778-z

47 Ferrari M, Zanasi A, Nardi E, et al. Short-term effects of a nicotine-free e-cigarette compared to a traditional cigarette in smokers and nonsmokers. BMC Pulm Med 2015;15:120. doi:10.1186/s12890-015 0106-z

48 Boulay ME, Henry C, Bossé Y, Boulet LP, Morissette MC. Acute effects of nicotine-free and flavour-free electronic cigarette use on lung functions in healthy and asthmatic individuals. Respir Res 2017:18:33. doi:10.1186/s12931-017-0518-9

49 Lappas AS, Tzortzi AS, Konstantinidi EM, et al. Short-term respiratory effects of e-cigarettes in healthy individuals and smokers with asthma. Respirology 2018;23:291-7. doi:10.1111/resp.13180

50 Meo SA, Ansary MA, Barayan FR, et al. Electronic Cigarettes: Impact on Lung Function and Fractional Exhaled Nitric Oxide Among Healthy Adults. Am J Mens Health 2019;13:1557988318806073. doi:10.1177/1557988318806073

51 Aurora P, Stanojevic S, Wade A, et al, London Cystic Fibrosis Collaboration. Lung clearance index at 4 years predicts subsequent lung function in children with cystic fibrosis. Am J Respir Crit Care Med 2011:183.752-8 doi:10.1164/rccm.200911-16460C

52 Woodruff PG, Barr RG, Bleecker E, et al, SPIROMICS Research Group. Clinical Significance of Symptoms in Smokers with Preserved Pulmonary Function. N Engl J Med 2016;374:1811-21. doi:10.1056/NEJMoa1505971

53 Coxson HO, Leipsic J, Parraga G, Sin DD. Using pulmonary imaging to move chronic obstructive pulmonary disease beyond FEV1. Am J Respir Crit Care Med 2014:190:135-44. doi:10.1164/rccm.201402 0256PP

54 Matthay MA, Ware LB, Zimmerman GA. The acute respiratory distress syndrome. / Clin Invest 2012;122:2731-40 doi:10.1172/JCl60331

55 Ghosh A, Coakley RC, Mascenik T, et al. Chronic E-Cigarette Exposure Alters the Human Bronchial Epithelial Proteome. Am J Respir Crit Care Med 2018:198:67-76. doi:10.1164/rccm.201710-20330C

56 Carter T, Tucker D, Kilic A, Papadimos TJ, Barlow A, Berry E. Life-threatening Vesicular Bronchial Injury Requiring Venovenous Extracorporeal Membrane Oxygenation Rescue in an Electronic Nicotine Delivery System User. Clin Pract Cases Emerg Med 2017;1:212-7. doi:10.5811/cpcem.2017.3.33171

57 Reidel B, Radicioni G, Clapp PW, et al. E-Cigarette Use Causes a Unique Innate Immune Response in the Lung, Involving Increased Neutrophilic Activation and Altered Mucin Secretion. Am J Respir Crit Care Med 2018;197:492-501. doi:10.1164/rccm.201708-15900C

58 Anderson WH, Coakley RD, Button B, et al. The Relationship of Mucus Concentration (Hydration) to Mucus Osmotic Pressure and Transport in Chronic Bronchitis. Am J Respir Crit Care Med 2015;192:182-90. doi:10.1164/rccm.201412-22300C

59 Kesimer M, Ford AA, Ceppe A, et al. Airway Mucin Concentration as a Marker of Chronic Bronchitis. N Engl J Med 2017;377:911-22 doi:10.1056/NEJMoa1701632

60 Malerba M, Radaeli A, Olivini A, et al. Exhaled nitric oxide as a biomarker in COPD and related comorbidities. Biomed Res Int 2014;2014:271918. doi:10.1155/2014/271918

61 Marini S, Buonanno G, Stabile L, Ficco G. Short-term effects of electronic and tobacco cigarettes on exhaled nitric oxide. Toxicol Appl Pharmacol 2014;278:9-15. doi:10.1016/j.taap.2014.04.004

62 Muley T, Wiebel M, Schulz V, Ebert W. Elastinolytic activity of alveolar macrophages in smoking-associated pulmonary emphysema. Clin Investig 1994;72:269-76. doi:10.1007/BF00180039

63 Harris JO, Olsen GN, Castle JR, Maloney AS. Comparison of proteolytic enzyme activity in pulmonary alveolar macrophages and blood leukocytes in smokers and nonsmokers. Am Rev Respir Dis $1975 ; 111: 579-86$
64 Takahashi H, Ishidoh K, Muno D, et al. Cathepsin L activity is increased in alveolar macrophages and bronchoalveolar lavage fluid of smokers. Am Rev Respir Dis 1993:147:1562-8. doi:10.1164/ ajrccm/147.6_Pt_1.1562

65 Weitz JI, Crowley KA, Landman SL, Lipman BI, Yu J. Increased neutrophil elastase activity in cigarette smokers. Ann Intern Med 1987;107:680-2. doi:10.7326/0003-4819-107-5-680

66 Shapiro SD, Goldstein NM, Houghton AM, Kobayashi DK, Kelley D, Belaaouaj A. Neutrophil elastase contributes to cigarette smokeinduced emphysema in mice. Am J Pathol 2003;163:2329-35. doi:10.1016/S0002-9440(10)63589-4

67 Churg A, Cosio M, Wright JL. Mechanisms of cigarette smoke-induced COPD: insights from animal models. Am I Physiol Lung Cell Mol Physiol 2008;294:L612-31. doi:10.1152/ajplung.00390.2007

68 Antunes MA, Rocco PR. Elastase-induced pulmonary emphysema: insights from experimental models. An Acad Bras Cienc 2011;83:1385-96. doi:10.1590/S000137652011005000039

69 Sohal SS, Reid D, Soltani A, et al. Reticular basement membrane fragmentation and potential epithelial mesenchymal transition is exaggerated in the airways of smokers with chronic obstructive pulmonary disease. Respirology 2010;15:930-8. doi:10.1111/ 1440-1843.2010.01808.x

70 Crystal RG. Alpha 1-antitrypsin deficiency, emphysema, and liver disease. Genetic basis and strategies for therapy. / Clin Invest 1990;85:1343-52. doi:10.1172/JCl114578

71 Stick SM, Brennan S, Murray C, et al, Australian Respiratory Early Surveillance Team for Cystic Fibrosis (AREST CF). Bronchiectasis in infants and preschool children diagnosed with cystic fibrosis after newborn screening. J Pediatr 2009;155:623-8.e1. doi:10.1016/j. jpeds.2009.05.005

72 Mason SD, Joyce JA. Proteolytic networks in cancer. Trends Cell Biol 2011:21:228-37 doi:10.1016/itcb.2010.12.002

73 Chaumont $M$, van de Borne P, Bernard A, et al. Fourth generation e-cigarette vaping induces transient lung inflammation and gas exchange disturbances: results from two randomized clinical trials. Am J Physiol Lung Cell Mol Physiol 2019;316:L705-19. doi:10.1152/ajplung.00492.2018

74 Moazed F, Burnham EL, Vandivier RW, et al. Cigarette smokers have exaggerated alveolar barrier disruption in response to lipopolysaccharide inhalation. Thorax 2016;71:1130-6. doi:10.1136/thoraxjnl-2015-207886

75 Moazed F, Calfee CS. Environmental risk factors for acute respiratory distress syndrome. Clin Chest Med 2014;35:625-37. doi:10.1016/j. ccm.2014.08.003

76 Viswam D, Trotter S, Burge PS, Walters GI. Respiratory failure caused by lipoid pneumonia from vaping e-cigarettes. BMJ Case Rep 2018;2018:bcr-2018-224350. doi:10.1136/bcr-2018224350

77 Thota D, Latham E. Case report of electronic cigarettes possibly associated with eosinophilic pneumonitis in a previously healthy active-duty sailor. J Emerg Med 2014:47:15-7. doi:10.1016/j. jemermed.2013.09.034

78 Agustin M, Yamamoto M, Cabrera F, Eusebio R. Diffuse Alveolar Hemorrhage Induced by Vaping. Case Rep Pulmonol 2018:2018:9724530 doi:10.1155/2018/9724530

79 Khan MS, Khateeb F, Akhtar J, et al. Organizing pneumonia related to electronic cigarette use: A case report and review of literature. Clin Respir / 2018;12:1295-9. doi:10.1111/cri.12775

80 Flower M, Nandakumar L, Singh M, Wyld D, Windsor M, Fielding D. Respiratory bronchiolitis-associated interstitial lung disease secondary to electronic nicotine delivery system use confirmed with open lung biopsy. Respirol Case Rep 2017;5:e00230. doi:10.1002/ rcr2.230

81 Sommerfeld CG, Weiner DJ, Nowalk A, Larkin A. Hypersensitivity Pneumonitis and Acute Respiratory Distress Syndrome From E-Cigarette Use. Pediatrics 2018;141:e20163927. doi:10.1542/ peds.2016-3927

82 Dicpinigaitis PV, Lee Chang A, Dicpinigaitis AJ, Negassa A. Effect of e-Cigarette Use on Cough Reflex Sensitivity. Chest 2016;149:161-5. doi:10.1378/chest.15-0817

83 Carson JL, Zhou L, Brighton L, et al. Temporal structure/function variation in cultured differentiated human nasal epithelium associated with acute single exposure to tobacco smoke or E-cigarette vapor. Inhal Toxicol 2017;29:137-44. doi:10.1080/0895 8378.2017.1318985

84 Martin EM, Clapp PW, Rebuli ME, et al. E-cigarette use results in suppression of immune and inflammatory-response genes in nasal epithelial cells similar to cigarette smoke. Am J Physiol Lung Cell Mol Physiol 2016;311:L135-44. doi:10.1152/ajplung.00170.2016

85 Law SM, Gray RD. Neutrophil extracellular traps and the dysfunctional innate immune response of cystic fibrosis lung disease: a review. J Inflamm (Lond) 2017:14:29. doi:10.1186/s12950-017-0176-1

86 Clapp PW, Pawlak EA, Lackey JT, et al. Flavored e-cigarette liquids and cinnamaldehyde impair respiratory innate immune cell function. Am 
J Physiol Lung Cell Mol Physiol 2017;313:L278-92. doi:10.1152/ ajplung.00452.2016

87 Proctor RN. The history of the discovery of the cigarettelung cancer link: evidentiary traditions, corporate denial, global toll. Tob Control 2012;21:87-91. doi:10.1136/ tobaccocontrol-2011-050338

88 Lorenz E, Stewart HL, Daniel JH, et al. The effects of breathing tobacco smoke on strain A mice. Cancer Res 1943;3:123.

89 Wynder EL, Graham EA, Croninger AB. Experimental production of carcinoma with cigarette tar. Cancer Res 1953;13:855-64

90 Larcombe AN, Janka MA, Mullins BJ, Berry LJ, Bredin A, Franklin $P$. The effects of electronic cigarette aerosol exposure on inflammation and lung function in mice. Am J Physiol Lung Cell Mol Physiol 2017;313:L67-79. doi:10.1152/ajplung.00203.2016

91 Lee HW, Park SH, Weng MW, et al. E-cigarette smoke damages DNA and reduces repair activity in mouse lung, heart, and bladder as well as in human lung and bladder cells. Proc Natl Acad Sci U S A 2018;115:E1560-9. doi:10.1073/pnas.1718185115

92 Khosravi M, Lin RL, Lee LY. Inhalation of electronic cigarette aerosol induces reflex bronchoconstriction by activation of vagal bronchopulmonary C-fibers. Am J Physiol Lung Cell Mol Physiol 2018;315:L467-75. doi:10.1152/ajplung.00137.2018

$93 \mathrm{Lim} \mathrm{HB}$, Kim SH. Inhallation of e-Cigarette Cartridge Solution Aggravates Allergen-induced Airway Inflammation and Hyperresponsiveness in Mice. Toxicol Res 2014;30:13-8. doi:10.5487/ TR.2014.30.1.013

94 Werley MS, Kirkpatrick DJ, Oldham MJ, et al. Toxicological assessment of a prototype e-cigaret device and three flavor formulations: a 90day inhalation study in rats. Inhal Toxicol 2016;28:22-38. doi:10.31 09/08958378.2015.1130758

95 Gotts JE, Matthay MA. Sepsis: pathophysiology and clinical management. BMJ 2016;353:i1585. doi:10.1136/bmj.i1585

96 Garcia-Arcos I, Geraghty P, Baumlin N, et al. Chronic electronic cigarette exposure in mice induces features of COPD in a nicotinedependent manner. Thorax 2016;71:1119-29. doi:10.1136/ thoraxinl-2015-208039

97 Sussan TE, Gajghate S, Thimmulappa RK, et al. Exposure to electronic cigarettes impairs pulmonary anti-bacterial and anti-viral defenses in a mouse model. PLoS One 2015;10:e0116861. doi:10.1371/ journal.pone.0116861

98 Miyashita L, Suri R, Dearing E, et al. E-cigarette vapour enhances pneumococcal adherence to airway epithelial cells. Eur Respir / 2018:51:1701592. doi:10.1183/13993003.01592-2017

99 Hwang JH, Lyes M, Sladewski K, et al. Electronic cigarette inhalation alters innate immunity and airway cytokines while increasing the virulence of colonizing bacteria. J Mol Med (Berl) 2016;94:667-79. doi:10.1007/s00109-016-1378-3

100 Webster MJ, Tarran R. Slippery When Wet: Airway Surface Liquid Homeostasis and Mucus Hydration. Curr Top Membr 2018;81:293335. doi:10.1016/bs.ctm.2018.08.004

101 Ghosh A, Boucher RC, Tarran R. Airway hydration and COPD. Cell Mol Life Sci 2015;72:3637-52. doi:10.1007/s00018-015-1946-7

102 Shivalingappa PC, Hole R, Westphal CV, Vij N. Airway Exposure to E-Cigarette Vapors Impairs Autophagy and Induces Aggresome Formation. Antioxid Redox Signal 2016;24:186-204. doi:10.1089/ ars.2015.6367

103 Lee KM, Hoeng J, Harbo S, et al. Biological changes in C57BL/6 mice following 3 weeks of inhalation exposure to cigarette smoke or e-vapor aerosols. Inhal Toxicol 2018;30:553-67. doi:10.1080/0895 8378.2019.1576807

104 Glynos C, Bibli SI, Katsaounou P, et al. Comparison of the effects of e-cigarette vapor with cigarette smoke on lung function and inflammation in mice. Am I Physiol Lung Cell Mol Physiol 2018;315:L662-72. doi:10.1152/ajplung.00389.2017

105 Phillips B, Titz B, Kogel U, et al. Toxicity of the main electronic cigarette components, propylene glycol, glycerin, and nicotine, in Sprague-Dawley rats in a 90-day OECD inhalation study complemented by molecular endpoints. Food Chem Toxicol 2017;109:315-32. doi:10.1016/j.fct.2017.09.001

106 Reinikovaite V, Rodriguez IE, Karoor V, et al. The effects of electronic cigarette vapour on the lung: direct comparison to tobacco smoke. Eur Respir / 2018;51:1701661. doi:10.1183/13993003.01661 2017

107 Crotty Alexander LE, Drummond CA, Hepokoski M, et al. Chronic inhalation of e-cigarette vapor containing nicotine disrupts airway barrier function and induces systemic inflammation and multiorgan fibrosis in mice. Am J Physiol Regul Integr Comp Physiol 2018;314:R834-47. doi:10.1152/ajpregu.00270.2017

108 Kozlowski LT, Whetzel CA, Stellman SD, O'Connor RJ. Ignoring puff counts: another shortcoming of the Federal Trade Commission cigarette testing programme. Tob Control 2008;17(Suppl 1):i6-9. doi:10.1136/tc.2007.020602

109 Dalhamn T. In vivo and in vitro ciliotoxic effects of tobacco smoke. Arch Environ Health 1970;21:633-4. doi:10.1080/00039896.1970 .10667307
110 Kaminski EJ, Fancher OE, Calandra JC. In vivo studies of the ciliastatic effects of tobacco smoke. Absorption of ciliastatic components by wet surfaces. Arch Environ Health 1968:16:188-93. doi:10.1080/00 039896.1968.10665042

111 Pettersson B, Curvall M, Enzell CR. Effects of tobacco smoke compounds on the ciliary activity of the embryo chicken trachea in vitro. Toxicology 1982;23:41-55. doi:10.1016/0300483X(82)90040-3

112 Agius AM, Smallman LA, Pahor AL. Age, smoking and nasal ciliary beat frequency. Clin Otolaryngol Allied Sci 1998;23:227-30. doi:10.1046/j.1365-2273.1998.00141.x

113 Lin VY, Fain MD, Jackson PL, et al. Vaporized E-Cigarette Liquids Induce Ion Transport Dysfunction in Airway Epithelia. Am J Respir Cell Mol Biol 2019;61:162-73. doi:10.1165/rcmb.2017-04320C

114 Chung S, Baumlin N, Dennis JS, et al. Electronic Cigarette Vapor with Nicotine Causes Airway Mucociliary Dysfunction Preferentially via TRPA1 Receptors. Am J Respir Crit Care Med 2019. doi:10.1164/ rccm.201811-20870C

115 Clapp PW, Lavrich KS, van Heusden CA, Lazarowski ER, Carson $J$ L, Jaspers I. Cinnamaldehyde in flavored e-cigarette liquids temporarily suppresses bronchial epithelial cell ciliary motility by dysregulation of mitochondrial function. Am I Physiol Lung Cell Mol Physiol 2019;316:L470-86. doi:10.1152/ajplung.00304.2018

116 Scott A, Lugg ST, Aldridge K, et al. Pro-inflammatory effects of e-cigarette vapour condensate on human alveolar macrophages. Thorax 2018;73:1161-9. doi:10.1136/thoraxinl-2018-211663

117 Sassano MF, Davis ES, Keating JE, et al. Evaluation of e-liquid toxicity using an open-source high-throughput screening assay. PLOS Biol 2018;16:e2003904. doi:10.1371/journal.pbio.2003904

118 Higham A, Rattray NJ, Dewhurst JA, et al. Electronic cigarette exposure triggers neutrophil inflammatory responses. Respir Res 2016;17:56. doi:10.1186/s12931-016-0368-x

119 Schweitzer KS, Chen SX, Law S, et al. Endothelial disruptive proinflammatory effects of nicotine and e-cigarette vapor exposures. Am J Physiol Lung Cell Mol Physiol 2015;309:L175-87. doi:10.1152/ajplung.00411.2014

120 Higham A, Bostock D, Booth G, Dungwa JV, Singh D. The effect of electronic cigarette and tobacco smoke exposure on COPD bronchial epithelial cell inflammatory responses. Int I Chron Obstruct Pulmon Dis 2018;13:989-1000 doi:10.2147/COPD.S157728

121 Moses E, Wang T, Corbett S, et al. Molecular Impact of Electronic Cigarette Aerosol Exposure in Human Bronchial Epithelium. Toxicol Sci 2017:155:248-57. doi:10.1093/toxsci/kfw198

122 Haswell LE, Baxter A, Banerjee A, et al. Reduced biological effect of e-cigarette aerosol compared to cigarette smoke evaluated in vitro using normalized nicotine dose and RNA-seq-based toxicogenomics. Sci Rep 2017;7:888. doi:10.1038/s41598-017-00852-y

123 Rayner RE, Makena P, Prasad GL, Cormet-Boyaka E. Cigarette and ENDS preparations differentially regulate ion channels and mucociliary clearance in primary normal human bronchial 3D cultures. Am J Physiol Lung Cell Mol Physiol 2019;317:L295-302. doi:10.1152/ajplung.00096.2019

124 Clunes LA, Davies CM, Coakley RD, et al. Cigarette smoke exposure induces CFTR internalization and insolubility, leading to airway surface liquid dehydration. FASEB J 2012;26:533-45. doi:10.1096/ fi.11-192377

125 Patel W, Moore PJ, Sassano MF, et al. Increases in cytosolic $\mathrm{Ca}^{2+}$ induce dynamin- and calcineurin-dependent internalisation of CFTR. Cell Mol Life Sci 2019;76:977-94. doi:10.1007/s00018-018-2989-

126 Rasmussen JE, Sheridan JT, Polk W, Davies CM, Tarran R. Cigarette smoke-induced $\mathrm{Ca} 2+$ release leads to cystic fibrosis transmembrane conductance regulator (CFTR) dysfunction. / Biol Chem 2014;289:7671-81. doi:10.1074/jbc.M113.545137

127 Einarsson GG, Comer DM, Mcllreavey L, et al. Community dynamics and the lower airway microbiota in stable chronic obstructive pulmonary disease, smokers and healthy non-smokers. Thorax 2016;71:795-803. doi:10.1136/thoraxjnl-2015-207235

128 Fodor AA, Klem ER, Gilpin DF, et al. The adult cystic fibrosis airway microbiota is stable over time and infection type, and highly resilient to antibiotic treatment of exacerbations. PLoS One 2012;7:e45001. doi:10.1371/journal.pone.0045001

129 Yaucher NE, Fish JT, Smith HW, Wells JA. Propylene glycolassociated renal toxicity from lorazepam infusion. Pharmacotherapy 2003;23:1094-9. doi:10.1592 phco.23.10.1094.32762

130 Blake DA, Whikehart DR, Yu H, Vogel T, Roberts DD. Common cryopreservation media deplete corneal endothelial cell plasma membrane $\mathrm{Na}+, \mathrm{K}+$ ATPase activity. Curr Eye Res 1996;15:263-71. doi:10.3109/02713689609007620

131 Morshed KM, Jain SK, McMartin KE. Acute toxicity of propylene glycol: an assessment using cultured proximal tubule cells of human origin. Fundam Appl Toxicol 1994:23:38-43, doi:10.1006/faat.1994.1076

132 Wieslander G, Norbäck D, Lindgren T. Experimental exposure to propylene glycol mist in aviation emergency training: acute ocular 
and respiratory effects. Occup Environ Med 2001;58:649-55. doi:10.1136/oem.58.10.649

133 Dalton P, Soreth B, Maute C, Novaleski C, Banton M. Lack of respiratory and ocular effects following acute propylene glycol exposure in healthy humans. Inhal Toxicol 2018;30:124-32. doi:10. 1080/08958378.2018.1470207

134 Bessac BF, Jordt SE. Breathtaking TRP channels: TRPA1 and TRPV1 in airway chemosensation and reflex control. Physiology (Bethesda) 2008;23:360-70. doi:10.1152/physiol.00026.2008

135 Niedermirtl F, Eberhardt M, Namer B, et al. Etomidate and propylene glycol activate nociceptive TRP ion channels. Mol Pain 2018;14:1744806918811699. doi:10.1177/1744806918811699

136 Caceres Al, Brackmann M, Elia MD, et al. A sensory neuronal ion channel essential for airway inflammation and hyperreactivity in asthma. Proc Natl Acad Sci U S A 2009;106:9099-104. doi:10.1073/pnas.0900591106

137 Verkman AS. Aquaporins in clinical medicine. Annu Rev Med 2012;63:303-16. doi:10.1146/annurev-med-043010-193843

138 Kreda SM, Gynn MC, Fenstermacher DA, Boucher RC, Gabriel $\mathrm{SE}$. Expression and localization of epithelial aquaporins in the adult human lung. Am J Respir Cell Mol Biol 2001;24:224-34. doi:10.1165/ajrcmb.24.3.4367

139 Madeira A, Moura TF, Soveral G. Aquaglyceroporins: implications in adipose biology and obesity. Cell Mol Life Sci 2015;72:759-71. doi:10.1007/s00018-014-1773-2

140 Pocivavsek L, Gavrilov K, Cao KD, et al. Glycerol-induced membrane stiffening: the role of viscous fluid adlayers. Biophys / 2011:101:118-27. doi:10.1016/j.bpj.2011.05.036

141 Zia S, Ndoye A, Nguyen VT, Grando SA. Nicotine enhances expression of the alpha 3, alpha 4, alpha 5, and alpha 7 nicotinic receptors modulating calcium metabolism and regulating adhesion and motility of respiratory epithelial cells. Res Commun Mol Pathol Pharmacol 1997;97:243-62.

142 Macklin KD, Maus AD, Pereira EF, Albuquerque EX, Conti-Fine BM. Human vascular endothelial cells express functional nicotinic acetylcholine receptors. J Pharmacol Exp Ther 1998;287:435-9.

143 Maus AD, Pereira EF, Karachunski PI, et al. Human and rodent bronchial epithelial cells express functional nicotinic acetylcholine receptors. Mol Pharmacol 1998;54:779-88. doi:10.1124/ mol.54.5.779

144 Conti-Fine BM, Navaneetham D, Lei S, Maus AD. Neuronal nicotinic receptors in non-neuronal cells: new mediators of tobacco toxicity?Eur J Pharmacol 2000;393:279-94. doi:10.1016/S00142999(00)00036-4

145 Maouche K. Medjber K, Zahm IM, et al. Contribution of a7 nicotinic receptor to airway epithelium dysfunction under nicotine exposure. Proc Natl Acad Sci U S A 2013;110:4099-104. doi:10.1073/ pnas.1216939110

146 Ahmad S, Zafar I, Mariappan N, et al. Acute pulmonary effects of aerosolized nicotine. Am J Physiol Lung Cell Mo Physiol 2019;316:L94-104. doi:10.1152/ajplung.00564.2017

147 Armstrong LW, Rom WN, Martiniuk FT, Hart D, Jagirdar J, Galdston M. Nicotine enhances expression of the neutrophil elastase gene and protein in a human myeloblast/promyelocyte cell line. Am J Respir Crit Care Med 1996:154:1520-4. doi:10.1164/ajrccm.154.5.8912774

148 Gomes JP, Watad A, Shoenfeld Y. Nicotine and autoimmunity: The lotus' flower in tobacco. Pharmacol Res 2018;128:101-9. doi:10.1016/j.phrs.2017.10.005

149 Egleton RD, Brown KC, Dasgupta P. Nicotinic acetylcholine receptors in cancer: multiple roles in proliferation and inhibition of apoptosis. Trends Pharmacol Sci 2008;29:151-8. doi:10.1016/j. tips.2007.12.006

150 Caporaso N, Gu F, Chatterjee N, et al. Genome-wide and candidate gene association study of cigarette smoking behaviors. PLOS One 2009; 4:e4653. doi:10.1371/journal.pone.0004653

151 Hung RJ, McKay JD, Gaborieau V, et al. A susceptibility locus for lung cancer maps to nicotinic acetylcholine receptor subunit genes on 15q25. Nature 2008;452:633-7. doi:10.1038/ nature 06885

152 Saccone NL, Wang JC, Breslau N, et al. The CHRNA5-CHRNA3-CHRNB4 nicotinic receptor subunit gene cluster affects risk for nicotine dependence in African-Americans and in European-Americans. Cancer Res 2009;69:6848-56. doi:10.1158/0008-5472.CAN-090786

153 Spitz MR, Amos Cl, Dong Q, Lin J, Wu X. The CHRNA5-A3 region on chromosome 15q24-25.1 is a risk factor both for nicotine dependence and for lung cancer. J Natl Cancer Inst 2008;100:1552 6. doi:10.1093/jnci/djn363

154 Lam DC, Girard L, Ramirez R, et al. Expression of nicotinic acetylcholine receptor subunit genes in non-small-cell lung cancer reveals differences between smokers and nonsmokers. Cancer Res 2007:67:4638-47. doi:10.1158/0008-5472.CAN-06-4628

155 Paleari L, Catassi A, Ciarlo M, et al. Role of alpha7-nicotinic acetylcholine receptor in human non-small cell lung cancer proliferation. Cell Prolif 2008;41:936-59. doi:10.1111/j.13652184.2008.00566.x

156 Babic M, Schuchardt M, Tölle M, van der Giet M. In times of tobaccofree nicotine consumption: The influence of nicotine on vascular calcification. Eur J Clin Invest 2019;49:e13077. doi:10.1111/ eci.13077

157 Chaumont M, de Becker B, Zaher W, et al. Differential Effects of E-Cigarette on Microvascular Endothelial Function, Arterial Stiffness and Oxidative Stress: A Randomized Crossover Trial. Sci Rep 2018;8:10378. doi:10.1038/s41598-018-28723-0

158 Klager S, Vallarino J, MacNaughton P, Christiani DC, Lu Q, Allen JG. Flavoring Chemicals and Aldehydes in E-Cigarette Emissions. Environ Sci Technol 2017:51:10806-13. doi:10.1021/acs.est.7b02205

159 Holden VK, Hines SE. Update on flavoring-induced lung disease. Curr Opin Pulm Med 2016;22:158-64. doi:10.1097/ MCP.0000000000000250

160 Gerloff J, Sundar IK, Freter R, et al. Inflammatory Response and Barrie Dysfunction by Different e-Cigarette Flavoring Chemicals Identified by Gas Chromatography-Mass Spectrometry in e-Liquids and e-Vapors on Human Lung Epithelial Cells and Fibroblasts. Appl In Vitro Toxicol 2017;3:28-40. doi:10.1089/aivt.2016.0030

161 Muthumalage T, Prinz M, Ansah KO, Gerloff J, Sundar IK, Rahman I. Inflammatory and Oxidative Responses Induced by Exposure to Commonly Used e-Cigarette Flavoring Chemicals and Flavored e-Liquids without Nicotine. Front Physiol 2018;8:1130. doi:10.3389/fphys.2017.01130

162 Behar RZ, Luo W, Lin SC, et al. Distribution, quantification and toxicity of cinnamaldehyde in electronic cigarette refill fluids and aerosols. Tob Control 2016;25(Suppl 2):ii94-102. doi:10.1136/ tobaccocontrol-2016-053224

163 Park HR, O'Sullivan M, Vallarino J, et al. Transcriptomic response of primary human airway epithelial cells to flavoring chemicals in electronic cigarettes. Sci Rep 2019;9:1400. doi:10.1038/s41598018-37913-9

164 Allen JG, Flanigan SS, LeBlanc M, et al. Flavoring Chemicals in E-Cigarettes: Diacetyl, 2,3-Pentanedione, and Acetoin in a Sample of 51 Products, Including Fruit-, Candy-, and CocktailFlavored E-Cigarettes. Environ Health Perspect 2016;124:733-9. doi:10.1289/ehp.1510185

165 Erythropel HC, Jabba SV, DeWinter TM, et al. Formation of flavorant-propylene Glycol Adducts With Novel Toxicological Properties in Chemically Unstable E-Cigarette Liquids. Nicotine Tob Res 2019;21:1248-58. doi:10.1093/ntr/nty192

166 Jensen RP, Luo W, Pankow JF, Strongin RM, Peyton DH. Hidden formaldehyde in e-cigarette aerosols. N Engl I Med 2015;372:392-4. doi:10.1056/NEJMc1413069

167 Salamanca JC, Meehan-Atrash J, Vreeke S, Escobedo JO, Peyton DH, Strongin RM. E-cigarettes can emit formaldehyde at high levels under conditions that have been reported to be non-averse to users. Sci Rep 2018:8:7559. doi:10.1038/s41598-018-25907-6

168 Samburova V, Bhattarai C, Strickland M, et al. Aldehydes in Exhaled Breath during E-Cigarette Vaping: Pilot Study Results. Toxics 2018:6:E46. doi:10.3390/toxics6030046

169 Sleiman M, Logue JM, Montesinos VN, et al. Emissions from Electronic Cigarettes: Key Parameters Affecting the Release of Harmful Chemicals. Environ Sci Technol 2016;50:9644-51. doi:10.1021/acs. est.6b01741

170 Bein K, Leikauf GD. Acrolein - a pulmonary hazard. Mol Nutr Food Res 2011;55:1342-60. doi:10.1002/mnfr.201100279

171 Haussmann HJ. Use of hazard indices for a theoretical evaluation of cigarette smoke composition. Chem Res Toxicol 2012;25:794-810. doi:10.1021/tx200536w

172 Kalkhoran S, Glantz SA. Modeling the Health Effects of Expanding e-Cigarette Sales in the United States and United Kingdom: A Monte Carlo Analysis. JAMA Intern Med 2015;175:1671-80. doi:10.1001/ jamainternmed.2015.4209

173 Warner KE, Mendez D. E-cigarettes: Comparing the Possible Risks of Increasing Smoking Initiation with the Potential Benefits of Increasing Smoking Cessation. Nicotine Tob Res 2019;21:41-7. doi:10.1093/ ntr/nty062

174 Larcombe AN. Early-life exposure to electronic cigarettes: cause for concern. Lancet Respir Med 2019;S2213-2600(19)30189-4. doi:10.1016/S2213-2600(19)30189-4

175 Visser WF, Klerx WN, Cremers HWJM, Ramlal R, Schwillens PL, Talhout R. The Health Risks of Electronic Cigarette Use to Bystanders. Int J Environ Res Public Health 2019;16:E1525. doi:10.3390/ ijerph16091525

176 Gentzke AS, Creamer M, Cullen KA, et al. Vital Signs: Tobacco Product Use Among Middle and High School Students - United States, 2011-2018. MMWR Morb Mortal Wkly Rep 2019;68:157-64. doi:10.15585/mmwr.mm6806e1

177 Kulik MC, Lisha NE, Glantz SA. E-cigarettes Associated With Depressed Smoking Cessation: A Cross-sectional Study of 28 European Union Countries. Am J Prev Med 2018;54:603-9. doi:10.1016/j.amepre.2017.12.017 
178 Kalkhoran S, Glantz SA. E-cigarettes and smoking cessation in real-world and clinical settings: a systematic review and metaanalysis. Lancet Respir Med 2016;4:116-28. doi:10.1016/S22132600(15)00521-4

179 Glantz SA, Bareham DW. E-Cigarettes: Use, Effects on Smoking, Risks, and Policy Implications. Annu Rev Public Health 2018;39:215-35. doi:10.1146/annurev-publhealth-040617-013757

180 Bullen C, Howe C, Laugesen M, et al. Electronic cigarettes for smoking cessation: a randomised controlled trial. Lancet 2013:382:1629-37. doi:10.1016/S0140-6736(13)61842-5

181 Caponnetto P, Campagna D, Cibella F, et al. Efficiency and Safety of an eLectronic cigAreTte (ECLAT) as tobacco cigarettes substitute: a prospective 12-month randomized control design study. PLoS One 2013;8:e66317. doi:10.1371/journal.pone.0066317

182 Borrelli B, O'Connor GT. E-Cigarettes to Assist with Smoking Cessation. N Engl J Med 2019;380:678-9. doi:10.1056/ NEJMe1816406

183 McNeill A, Brose L, Calder R, et al. E-Cigarettes: An Evidence Update. A Report Commissioned by Public Health England. Public Health England, 2015

184 Ferkol TW, Farber HJ, La Grutta S, et al, Forum of International Respiratory Societies. Electronic cigarette use in youths: a position statement of the Forum of International Respiratory Societies. Eur Respir / 2018;51:1800278. doi:10.1183/13993003.00278-2018

185 Livingston CJ, Freeman RJ, Costales VC, et al. Electronic Nicotine Delivery Systems or E-cigarettes: American College of Preventive Medicine's Practice Statement. Am J Prev Med 2019;56:167-78. doi:10.1016/j.amepre.2018.09.010
186 Douglas CE, Henson R, Drope J, Wender RC. The American Cancer Society public health statement on eliminating combustible tobacco use in the United States. CA Cancer J Clin 2018;68:240-5. doi:10.3322/caac. 21455

187 Royal College of Physicians. Nicotine without smoke: Tobacco harm reduction. 2016. https://www.rcplondon.ac.uk/projects/outputs/ nicotine-without-smoke-tobacco-harm-reduction-0.

188 Leone FT, Carlsen KH, Chooljian D, et al. Recommendations for the Appropriate Structure, Communication, and Investigation of Tobacco Harm Reduction Claims. An Official American Thoracic Society Policy Statement. Am J Respir Crit Care Med 2018;198:e90-105. doi:10.1164/rccm.201808-1443ST

189 European Public Health Association. Facts and fiction on e-cigs. 2018. https://eupha.org/repository/advocacy/EUPHA_facts_and_ fiction_on_e-cigs.pdf.

190 Bals R, Boyd J, Esposito S, et al. Electronic cigarettes: a task force report from the European Respiratory Society. Eur Respir / 2019;53:1801151. doi:10.1183/13993003.01151-2018

191 Cummings KM, Morris PB, Benowitz NL. Another Article About E-Cigarettes: Why Should I Care?J Am Heart Assoc 2018;7:e009944. doi:10.1161/JAHA.118.009944

192 Chadi N, Hadland SE, Harris SK. Understanding the implications of the "vaping epidemic" among adolescents and young adults: A call for action. Subst Abus 2019;40:7-10. doi:10.1080/08897077.2019.1 580241

193 Cooper EC, Hoyle PC. Guidance for Industry. 1989. https://www.fda. gov/downloads/Drugs/GuidanceComplianceRegulatorylnformation/ Guidances/UCM079262.pdf. 